\title{
Taxonomic assessment and distribution of fishes in upper Kura and Aras river drainages
}

\author{
Cüneyt Kaya ${ }^{1}$, Esra Bayçelebi ${ }^{1}$, Davut Turan ${ }^{1}$ \\ 1 Recep Tayyip Erdogan University, Faculty of Fisheries and Aquatic Sciences, 53100 Rize, Turkey \\ http://zoobank.org/531B8DC0-565A-497B-B390-B6F9A7444082 \\ Corresponding author: Cüneyt Kaya (cnytkaya@yahoo.com)
}

Academic editor: Nicolas Hubert • Received 19 March 2020 • Accepted 18 May 2020 • Published 15 June 2020

\begin{abstract}
In the present study, the actual fish fauna of the upper Kura and Aras river drainages in Turkey were re-examined. The distribution and latest taxonomic status of the species were assessed. The study area comprises the upper part of Kura and Aras river drainages, in Turkey. Overall, 32 sampling sites were prospected between 2004-2018 to inventory fish species in the area and a total of 33 species were recognized, five of which are recorded for the first time from the Turkish part of upper Aras river drainage, namely Alburnus hohenackeri, Blicca bjoerkna, Gobio artvinicus, Neogobius fluviatilis and Rhodeus amarus.
\end{abstract}

\section{Key Words}

Anatolia, biodiversity, Caspian Sea basin; fish fauna

\section{Introduction}

The Kura and Aras rivers and their tributaries are located in the south of the Caucasus Mountains. Both rivers originate in Anatolia and flow towards the east. Kura, after leaving the borders of Turkey, passes through Georgia, and then flows into Azerbaijan. Aras, before leaving Turkey, flows along the borders between Turkey and Armenia, between Turkey and Nakhchivan and then flows throughout the borders between Iran and three countries (Nakhchivan, Armenia and Azerbaijan, respectively). Both rivers further merge in Sabirabad (Azerbaijan) and flow into the Caspian Sea.

Fricke et al. (2007) recorded many fish species new to Turkish freshwaters. Most of these records were given from some of the transboundary rivers (e.g. Maritza, Orontes, Tigris-Euphrates and Kura-Aras river systems, and Çoruh River). These records were partially accepted and followed as most of these new occurrences were not ascertained through specimens deposited in a national collection. This situation has caused an overestimate of the number of freshwater fish species in Turkey (Çiçek et al. 2015, 2018).
Çiçek and Sungur Birecikligil (2016) listed fish species of the upper Kura-Aras River drainages based on their own observations and earlier records in the literature. They observed 19 species but listed 32 species by including 13 species that were recorded in the previous studies.

Inconsistent and erroneous occurrence records of species given by previous studies from upper Kura and Aras drainages have resulted in contradictory taxonomic evaluations among researchers. Therefore, here we attempt to re-assess the fish fauna of the upper Kura and Aras river drainages based on materials from our field surveys and up-to-date taxonomic nomenclature.

\section{Material and methods}

\section{Study area}

The study area comprises the upper part of Kura and Aras river drainages, the Caspian Sea basin. Overall, 32 sampling sites, 9 from Kura and 23 from Aras drainages, were detected to reveal fishes in the area (Table 1). 


\section{Data collection and analyses}

Fishes were caught between 2004-2018 by Samus 1000 pulsed DC electro-fishing equipment, cast and gill nets from 32 sampling sites (Fig. 1). After anaesthesia, fish specimens were fixed in $4 \%$ formaldehyde and transferred to the laboratory for further identification. Formalin-fixed specimens were deposited at FFR (Recep Tayyip Erdogan University Zoology Museum of the Faculty of Fisheries, Rize). We followed Berg (1949) and Kottelat and Freyhof (2007) to identify species, Van der Laan et al. (2015) to arrange species in families. All species were arranged alphabetically within their own families. Common and local names of the species originate from FishBase (Froese and Pauly 2019). If the species are unnamed or do not have a proper name, new names are recommended in this study. The new names are denoted by an asterisk $(*)$ at the end of the name. The global conservation status of the species is provided by International Union for Conservation of Nature (IUCN 2020).

\section{Results}

Overall, 33 fish species (Table 1) belonging to nine families were recognized. The most species-rich family in the area is Leuciscidae (10 species), followed by Cyprinidae (7), Salmonidae (4), Gobionidae (3), Nemacheilidae (3), Cobitidae (2), Gobiidae (2), Acheilognathidae (1) and Siluridae (1).

Twenty species, which were reported in earlier studies, were excluded from the fish fauna of the upper Kura-Aras drainages. Some of these species were already highlighted as declining by some authors or accepted as extinct (See Table 2 for details). Alburnus hohenackeri Kessler, 1877, Blicca bjoerkna (Linnaeus, 1758), Gobio artvinicus Turan, Japoshvili, Aksu \& Bektaş, 2016, Neogobius fluviatilis (Pallas, 1814) and Rhodeus amarus (Bloch, 1782) were recorded for the first time from the upper reaches of Aras River in Turkey. Among these species, Alburnus hohenackeri was recorded by Fricke et al. (2007) and Çiçek

Table 1. The species observed in this study according to the sampling sites.

\begin{tabular}{|c|c|c|c|c|}
\hline & No & Sampling Site & Coordinates & Observed Species \\
\hline \multirow{9}{*}{$\begin{array}{l}\frac{1}{2} \\
\frac{2}{\alpha} \\
\frac{\pi}{3} \\
\frac{1}{3}\end{array}$} & 1 & $\begin{array}{l}\text { Stream Karaman at } \\
\text { Aşızzülal }\end{array}$ & $41.4371 \mathrm{~N}, 42.6226 \mathrm{E}$ & Alburnoides eichwaldii, Barbus cyri, Ponticola cyrius \\
\hline & 2 & Stream Çöt Suyu & $41.2998 \mathrm{~N}, 42.7087 \mathrm{E}$ & Alburnoides eichwaldii \\
\hline & 3 & $\begin{array}{l}\text { Stream Kınavur at } \\
\text { Çataldere }\end{array}$ & $41.1976 \mathrm{~N}, 42.6135 \mathrm{E}$ & Salmo caspius \\
\hline & 4 & Stream Açıkyazı & $41.1443 \mathrm{~N}, 42.5908 \mathrm{E}$ & Squalius agdamicus \\
\hline & 5 & Stream Toros & $41.1115 \mathrm{~N}, 42.4468 \mathrm{E}$ & Salmo caspius \\
\hline & 6 & $\begin{array}{l}\text { Kura River at } \\
\text { Yalnızçam }\end{array}$ & $41.0709 \mathrm{~N}, 42.4844 \mathrm{E}$ & $\begin{array}{c}\text { Alburnoides eichwaldii, Alburnus filipii, Barbus cyri, Capoeta capoeta, Carassius gibelio, Leucalburnus } \\
\text { satunini, Romanogobio macropterus, Squalius agdamicus }\end{array}$ \\
\hline & 7 & Stream Çakır & $40.9669 \mathrm{~N}, 42.5861 \mathrm{E}$ & $\begin{array}{c}\text { Acanthobrama microlepis, Alburnoides eichwaldii, Alburnus filippii, Barbus cyri, Capoeta capoeta, } \\
\text { Chondrostoma cyri, Leucalburnus satunini, Oxynoemacheilus cyri, Romanogobio macropterus, } \\
\text { Sabanejewia aurata, Squalius agdamicus }\end{array}$ \\
\hline & 8 & Stream Ölçek & $41.1340 \mathrm{~N}, 42.8560 \mathrm{E}$ & $\begin{array}{c}\text { Acanthobrama microlepis, Alburnoides eichwaldii, Alburnus filippii, Barbus cyri, Capoeta capoeta, } \\
\text { Leucalburnus satunini, Oxynoemacheilus brandtii, O. cyri, Ponticola cyrius, Sabanejewia aurata, Squalius } \\
\text { agdamicus }\end{array}$ \\
\hline & 9 & Lake Aktaş & $41.1917 \mathrm{~N}, 43.1737 \mathrm{E}$ & Pseudorasbora parva \\
\hline \multirow{23}{*}{ 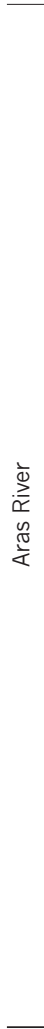 } & 10 & Stream Doğruyol & $41.0620 \mathrm{~N}, 43.3450 \mathrm{E}$ & Acanthobrama microlepis, Alburnus filipii, Capoeta capoeta, Oxynoemacheilus veyselorum \\
\hline & 11 & Lake Çıldır & $41.0449 \mathrm{~N}, 43.2804 \mathrm{E}$ & $\begin{array}{c}\text { Alburnoides eichwaldii, Alburnus filippii, Barbus cyri, Capoeta capoeta, Carassius gibelio, Chondrostoma } \\
\text { cyri, Cyprinus carpio, Leuciscus aspius, Oncorhynchus mykiss, Squalius turcicus }\end{array}$ \\
\hline & 12 & Stream Büyük Çayır & $40.8431 \mathrm{~N}, 43.3222 \mathrm{E}$ & Alburnus filippii, Oxynoemacheilus brandtii, O. veyselorum \\
\hline & 13 & Stream Fehmiharabesi & $40.7723 \mathrm{~N}, 43.2959 \mathrm{E}$ & $\begin{array}{c}\text { Alburnoides eichwaldii, Alburnus filippii, Barbus cyri, Capoeta capoeta, Oxynoemacheilus brandtii, O. } \\
\text { veyselorum, Sabanejewia aurata, Squalius turcicus }\end{array}$ \\
\hline & 14 & Stream Tahtakaya & $40.8539 \mathrm{~N}, 43.0188 \mathrm{E}$ & Salmo aff. caspius \\
\hline & 15 & Stream Kayalık & $40.8201 \mathrm{~N}, 43.1268 \mathrm{E}$ & Salmo aff. caspius \\
\hline & 16 & Stream Incilipınar & $40.8211 \mathrm{~N}, 43.0751 \mathrm{E}$ & Salmo aff. caspius \\
\hline & 17 & Steam Susuz at Susuz & $40.7806 \mathrm{~N}, 43.1411 \mathrm{E}$ & Alburnoides eichwaldii, Alburnus filippii, Capoeta capoeta \\
\hline & 18 & Stream Kars & $40.5814 \mathrm{~N}, 43.0591 \mathrm{E}$ & $\begin{array}{l}\text { Alburnoides eichwaldii, Alburnus filippii, Barbus cyri, Capoeta capoeta, Chondrostoma cyri, Cobitis } \\
\text { saniae, Squalius turcicus, Silurus glanis, Oxynoemacheilus veyselorum, Romanogobio macropterus }\end{array}$ \\
\hline & 19 & Stream Maksutçuk & $40.5160 \mathrm{~N}, 42.9510 \mathrm{E}$ & Alburnoides eichwaldii, Alburnus filippii, Barbus cyri, Capoeta capoeta \\
\hline & 20 & $\begin{array}{l}\text { Stream Kekeç at } \\
\text { Selim }\end{array}$ & $40.4715 \mathrm{~N}, 42.8005 \mathrm{E}$ & $\begin{array}{c}\text { Alburnoides eichwaldii, Alburnus filippii, Barbus cyri, Capoeta capoeta, Cobitis saniae, Oxynoemacheilus } \\
\text { brandtii, O. veyselorum, Squalius turcicus }\end{array}$ \\
\hline & 21 & Stream Boyalı & $40.4478 \mathrm{~N}, 42.5833 \mathrm{E}$ & $\begin{array}{c}\text { Alburnoides eichwaldii, Alburnus filippii, Barbus cyri, Capoeta capoeta, Oxynoemacheilus veyselorum, } \\
\text { Squalius turcicus }\end{array}$ \\
\hline & 22 & Stream Kars at Çatak & $40.4016 \mathrm{~N}, 42.6783 \mathrm{E}$ & Alburnoides eichwaldii, Squalius turcicus \\
\hline & 23 & Stream Kızılçubuk & $40.3736 \mathrm{~N}, 42.5366 \mathrm{E}$ & Alburnoides eichwaldii, Capoeta capoeta, Oxynoemacheilus veyselorum \\
\hline & 24 & Stream Keklik & $40.2955 \mathrm{~N}, 42.6565 \mathrm{E}$ & Barbus cyri, Salmo cf. ciscaucasicus \\
\hline & 25 & Aras River at Köprüçay & $39.9699 \mathrm{~N}, 41.8883 \mathrm{E}$ & $\begin{array}{c}\text { Alburnoides eichwaldii, Acanthobrama microlepis, Alburnus filippii, Capoeta capoeta, Cobitis saniae, } \\
\text { Romanogobio macropterus, Squalius turcicus }\end{array}$ \\
\hline & 26 & Stream Digor & $40.3731 \mathrm{~N}, 43.4271 \mathrm{E}$ & $\begin{array}{c}\text { Alburnoides eichwaldii, Barbus cyri, Capoeta capoeta, Oxynoemacheilus brandtii, O. veyselorum, Squalius } \\
\text { turcicus }\end{array}$ \\
\hline & 27 & $\begin{array}{l}\text { Aras River west of } \\
\text { Donandı }\end{array}$ & $40.1097 \mathrm{~N}, 43.4349 \mathrm{E}$ & Alburnoides eichwaldii, Acanthobrama microlepis, Capoeta capoeta \\
\hline & 28 & Stream Gaziler & $40.1072 N, 43.4513 E$ & $\begin{array}{l}\text { Acanthobrama microlepis, Alburnoides eichwaldii, Alburnus filippii, Barbus cyri, Carassius gibelio, } \\
\text { Cyprinus carpio, Luciobarbus capito, Luciobarbus mursa, Oxynoemacheilus brandtii }\end{array}$ \\
\hline & 29 & Lake Balık & $39.7451 \mathrm{~N}, 43.5385 \mathrm{E}$ & Barbus cyri, Cyprinus carpio, Squalius turcicus, Capoeta capoeta, Salmo cf. ciscaucasicus \\
\hline & 30 & Stream Aktarla & $39.7373 \mathrm{~N}, 43.5815 \mathrm{E}$ & Alburnoides eichwaldii, Barbus cyri \\
\hline & 31 & Stream Sarısu & $39.5409 \mathrm{~N}, 44.0044 \mathrm{E}$ & Barbus cyri, Capoeta capoeta \\
\hline & 32 & B.20 canal at Aralık & $39.8936 \mathrm{~N}, 44.5256 \mathrm{E}$ & $\begin{array}{c}\text { Alburnoides eichwaldii, Alburnus filippii, A. hohenackeri Barbus cyri, Blicca bjoerkna, Capoeta kaput, } \\
\text { Chondrostoma cyri, Cyprinus carpio, Gobio artvinicus, Neogobius fluviatilis, Rhodeus amarus, Silurus } \\
\text { glanis, Squalius turcicus }\end{array}$ \\
\hline
\end{tabular}




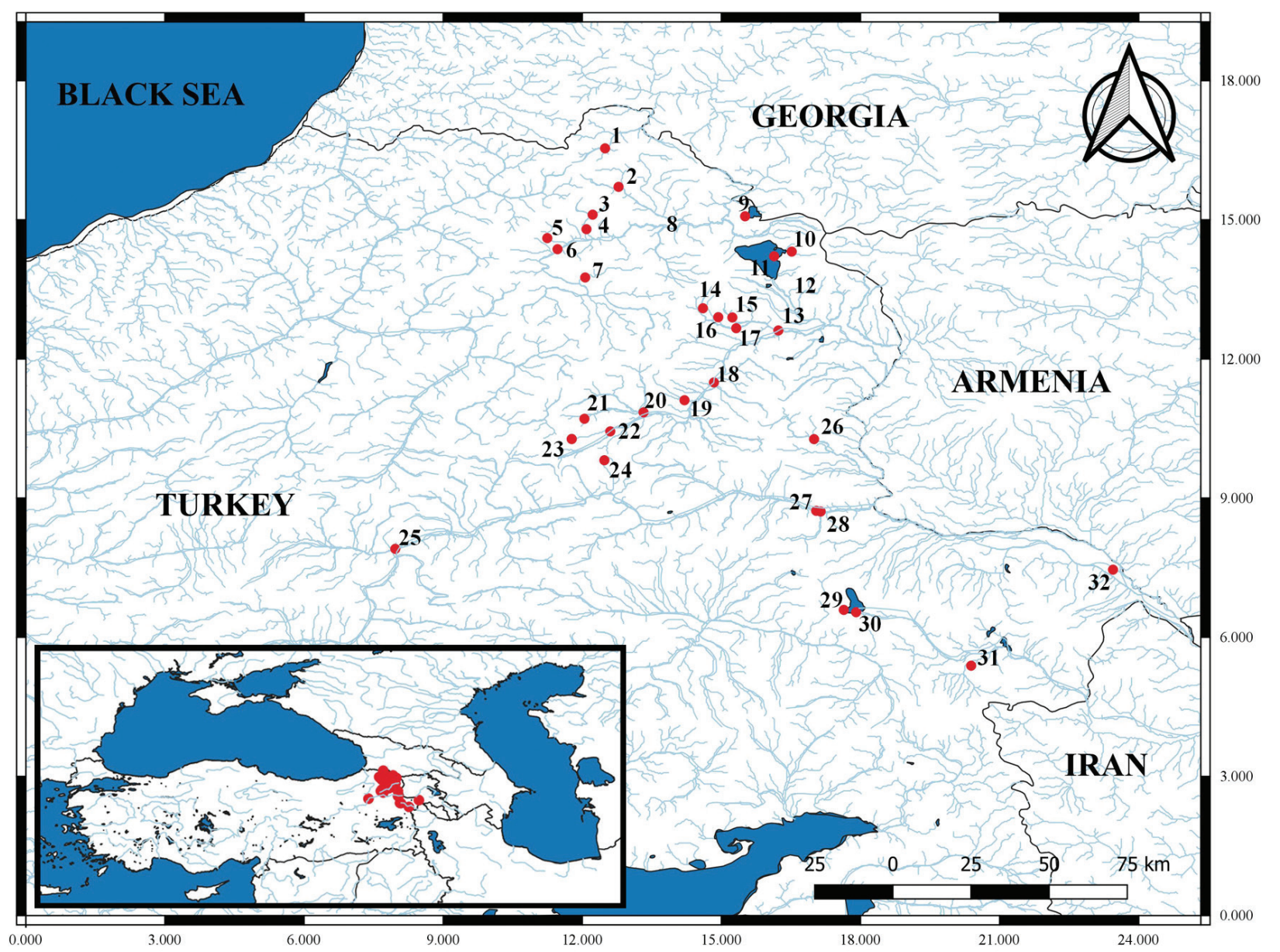

Figure 1. Distribution of the sampling sites in the area. Numbers refer the sampling sites indicated in Table 1.

et al. (2015), Blicca bjoerkna (as Abramis bjoerkna) by Fricke et al. (2007). In this study, however, the occurrence of these species was documented for the first time based on newly collected specimens deposited at Recep Tayyip Erdogan University Zoology Museum of the Faculty of Fisheries, Rize.

\section{Family Cyprinidae}

\section{Barbus cyri De Filippi, 1865}

Fig. 2a

Common / local names. Kura barbel / Kura bıyıklı balığı.

IUCN status. Not evaluated (NE).

Examined material. FFR 194, Stream Karaman at Aşıkzülal, Kura drainage, 41.4413N, 42.6591E. -FFR 219, Kura River at Yalnızçam, 41.0709N, 42.4844E. FFR 234, Stream Çakır, $3 \mathrm{~km}$ south of Çakıldere, Kura drainage, 40.9669N, 42.5861E. -FFR 166, Stream Ölçek at Ölçek, Kura drainage, 41.1340N, 42.8560E. -FFR 217, Lake Çıldır, Aras drainage, 41.0449N, 43.2804E. -FFR 8817, Stream Fehmiharabesi at Akçalar, Aras drainage, 40.7723N, 43.2959E. Not preserved, Stream Kars at campus of Kafkas University, Aras drainage, 40.5814N,
43.0591E. -FFR 188, Stream Maksutçuk west of Dikme, Aras drainage, 40.5160N, 42.9510E. -FFR 195, Stream Kekeç at Selim, Aras drainage, 40.4715N, 42.8005E. -FFR 216, Stream Boyal1 at Boyal1, Aras drainage, 40.4478N, 42.5833E. -FFR 165, Stream Keklik $6 \mathrm{~km}$ southeast of Sarıkamış, Aras drainage, 40.2955N, 42.6565E. -FFR 220, Stream Digor at Digor, Aras drainage, 40.3731N, 43.4271E. -FFR 215, Stream Gaziler, $2 \mathrm{~km}$ west of Donand1, Aras drainage, 40.1097N, 43.4349E. Not preserved, Lake Balık at Tanyolu, Aras drainage, 39.7451N, 43.5385E. -FFR 8804, Stream Aktarla at Aktarla, a southern drainage of Lake Balık, 39.7373N, 43.5815E. -FFR 221, Stream Sarısu West of Doğubeyazit, Aras drainage, 39.5409N, 44.0044E. -FFR 233, B-20 canal at Aralı, Aras drainage, $39.8936 \mathrm{~N}, 44.5256 \mathrm{E}$.

Distribution in the area. Widespread in tributaries of Kura and Aras rivers.

\section{Capoeta capoeta (Güldenstädt, 1773)}

Fig. 2b

Common / local names. Seven khramulya; Caucasian scraper*/Kafkasya siraz1*.

IUCN status. Least concern (LC). 
Table 2. List of the species to be excluded from the checklist of Kura-Aras drainages in Turkey.

\begin{tabular}{|c|c|c|}
\hline & Species & Explanation \\
\hline 1 & $\begin{array}{l}\text { Abramis brama } \\
\text { (Linnaeus, 1758) }\end{array}$ & $\begin{array}{l}\text { The species reported in the Turkish Kura and Aras drainages by Fricke et al. (2007). Actually, the species is distributed } \\
\text { in the Caspian Sea and it is possible to occur in Turkey. However, it was not found by Çiçek and Sungur Birecikligil } \\
\text { (2016), as well as in our surveys in the area. Therefore, it was omitted from the fishes of upper Kura and Aras } \\
\text { drainages until the species has been documented by the observed material. }\end{array}$ \\
\hline 2 & $\begin{array}{l}\text { Acipenser persicus } \\
\text { Borodin, } 1897\end{array}$ & $\begin{array}{l}\text { The species was erroneously reported in the upper Aras drainages by Fricke et al. (2007), followed by Çiçek et al. } \\
\text { (2015) and Çiçek and Sungur Birecikligil (2016). The species has not been documented by the observed material. }\end{array}$ \\
\hline 3 & \begin{tabular}{|l|} 
Alburnus chalcoides \\
(Güldenstädt, 1772)
\end{tabular} & $\begin{array}{l}\text { Because of the problematic taxonomy of the genus (Bogutskaya et al. 2017), the species was recorded in the Black Sea } \\
\text { and the Caspian Sea basin in Turkey by many researchers (e.g. Turan 2003; Geldiay and Balık 2007; Fricke et al. 2007; } \\
\text { Çiçek et al. 2015). However, the occurrence of the third shemaya, except A. filippii and A. hohenackeri, has never been } \\
\text { documented by the observed material. }\end{array}$ \\
\hline 4 & $\begin{array}{l}\text { Alosa caspia } \\
\text { (Eichwald, 1838) }\end{array}$ & $\begin{array}{l}\text { This predominantly marine and estuarine species has never been observed in any parts of the Turkish Kura and Aras } \\
\text { drainages, except erroneously in a report by Fricke et al. (2007), followed by Çiçek et al. (2015) and Çiçek and Sungur } \\
\text { Birecikligil (2016). }\end{array}$ \\
\hline 5 & $\begin{array}{l}\text { Alosa braschnikowi } \\
\text { (Borodin, 1904) }\end{array}$ & $\begin{array}{l}\text { The species was recorded in Turkish Aras drainages as Rutilus sojuchbulagi (Fricke et al. 2007). However, it is a brackish } \\
\text { species and nonanadrom (Afraei Bandpei et al. 2012). Therefore, the occurrence of the species in the Turkish Aras } \\
\text { River is not deemed likely. }\end{array}$ \\
\hline 6 & $\begin{array}{l}\text { Caspiomyzon wagneri } \\
\text { (Kessler, 1870) }\end{array}$ & $\begin{array}{l}\text { It is an endemic lamprey to the Caspian Sea basin and may be extinct from Kura (Berg 1949). It was claimed that the } \\
\text { species was extinct in Turkey (Fricke et al. 2007; Çiçek and Sungur Birecikligil 2016). However, the species has never } \\
\text { been reported in Turkey. }\end{array}$ \\
\hline 7 & $\begin{array}{l}\text { Chelon saliens (Risso, } \\
1810 \text { ) }\end{array}$ & $\begin{array}{l}\text { The species has never been reported in the upper Kura and Aras drainages until an erroneous record by Fricke et al. } \\
\text { (2007). The record was not supported by the following researchers (Çiçek et al. 2015; Çiçek and Sungur Birecikligil } \\
\text { 2016). }\end{array}$ \\
\hline 8 & $\begin{array}{l}\text { Gambusia holbrooki } \\
\text { Girard, } 1859\end{array}$ & $\begin{array}{l}\text { Erroneously reported to be in the upper Aras drainages based on the following literature "Kuru 2004, Fricke et al. 2007; } \\
\text { Çiçek et al. 2015". However, none of these studies had directly reported this species in the area. }\end{array}$ \\
\hline 9 & $\begin{array}{l}\text { Luciobarbus caspius } \\
\text { Berg, } 1914\end{array}$ & $\begin{array}{l}\text { The species erroneously reported in the upper Aras drainage by Fricke et al. (2007), followed by Çiçek et al. (2015) and } \\
\text { Çiçek and Sungur Birecikligil (2016). The species has not been documented by the observed material. }\end{array}$ \\
\hline 10 & $\begin{array}{l}\text { Luciobarbus } \\
\text { brachycephalus } \\
\text { (Kessler, 1872) }\end{array}$ & $\begin{array}{l}\text { Fricke et al. (2007) verified the presence of the species from Hasankale Stream (Erzurum Province) based on museum } \\
\text { material. However, this claim has not been supported by the following researchers (Çiçek et al. 2015; Çiçek and Sungur } \\
\text { Birecikligil 2016). The species reported from the lower Aras river (Coad 2020). Even though we have a sampling site } \\
\text { close to Hasankale, we did not observe the species in the area. Moreover, a third Luciobarbus species, except } L \text {. capito } \\
\text { and } L \text {. mursa, was not found in the upper Aras drainages. Perhaps, the museum material presented by Fricke et al. } \\
\text { (2007) was mislabelled or misidentified. We omitted it from the fishes of upper Kura and Aras drainages until the } \\
\text { species has been documented by the observed material. }\end{array}$ \\
\hline 11 & $\begin{array}{l}\text { Neogobius } \\
\text { melanostomus } \\
\text { (Pallas, 1814) }\end{array}$ & \multirow{3}{*}{$\begin{array}{l}\text { These three gobiid species had never been reported in the upper Kura and Aras drainages until they were erroneously } \\
\text { recorded by Fricke et al. (2007). These records were not supported by the following researchers (Çiçek et al. 2015; } \\
\text { Çiçek and Sungur Birecikligil 2016). We omitted them from the fishes of upper Kura and Aras drainages until the } \\
\text { species have been documented by the observed material. }\end{array}$} \\
\hline 12 & $\begin{array}{l}\text { Neogobius syrman } \\
\text { (Pallas, 1814) }\end{array}$ & \\
\hline 13 & $\begin{array}{l}\text { Ponticola ratan } \\
\text { (Pallas, 1814) }\end{array}$ & \\
\hline 14 & $\begin{array}{l}\text { Proterorhinus } \\
\text { marmoratus (Pallas, } \\
\text { 1814) }\end{array}$ & $\begin{array}{l}\text { The species reported from lower reaches of Aras, near Baku (Kessler 1877; Derzhavin 1934; Berg 1949). Erroneously } \\
\text { reported in the upper Aras drainages by Fricke et al. (2007). They also claimed the species was extinct in the Caspian } \\
\text { Sea watersheds. }\end{array}$ \\
\hline 15 & $\begin{array}{l}\text { Romanogobio persus } \\
\text { (Günther, 1899) }\end{array}$ & $\begin{array}{l}\text { The type locality of this species from Gader Chai, Lake Urmia basin. The specimens collected from Horasan (Erzurum) } \\
\text { were identified as } R \text {. persus (Kuru, 1975). This record was followed by Kuru (2004) and, Fricke et al. (2007). However, } \\
\text { Çiçek et al. (2015) and Çiçek and Sungur Birecikligil (2016), claimed that maybe the species was misidentified. We } \\
\text { omitted the species from the fishes of upper Kura and Aras drainages for now. See remarks of R. macropterus for } \\
\text { details about the taxonomy of Romanogobio populations in the area. }\end{array}$ \\
\hline 16 & $\begin{array}{l}\text { Rutilus kutum } \\
\text { (Kamensky, 1901) }\end{array}$ & $\begin{array}{l}\text { The species recorded from Turkey as Rutilus frisii caspius Kuru (2004), later synonymised with R. kutum (Bogutskaya and } \\
\text { lliadou 2006). This record was followed by Fricke et al. (2007). However, the occurrence of the species has never been } \\
\text { documented by the observed material. Recently, Kuljanishvili et al. (2020) treated R. kutum as a junior synonym of } R \text {. frisii. }\end{array}$ \\
\hline 17 & $\begin{array}{l}\text { Sabanejewia caspia } \\
\text { (Eichwald, 1838) }\end{array}$ & $\begin{array}{l}\text { The species reported in the upper Kura and Aras drainages by Fricke et al. (2007), probably instead of S. aurata which } \\
\text { had already been known in the area. This report followed by Çiçek et al. (2015) and Çiçek and Sungur Birecikligil } \\
\text { (2016). The species is distributed in the southern Caspian Sea basin (Anzali wetland, Sefid River and Amirkolayeh } \\
\text { Wetland) (Sayyadzadeh et al. 2018) }\end{array}$ \\
\hline 18 & $\begin{array}{l}\text { Sander lucioperca } \\
\text { (Linnaeus, 1758) }\end{array}$ & $\begin{array}{l}\text { It was reported that the species spawned in the lower and middle Kura River (Berg 1949). Çiçek and Sungur Birecikligil } \\
\text { (2016) erroneously reported it in the upper Aras drainages based on the following literature "Kuru 2004, Fricke et al. } \\
\text { 2007; Çiçek et al. 2015". However, none of these studies had reported this species in the area. }\end{array}$ \\
\hline 19 & $\begin{array}{l}\text { Squalius orientalis } \\
\text { Heckel, } 1847\end{array}$ & $\begin{array}{l}\text { The species was erroneously reported in the upper Aras drainages by Çiçek et al. (2015) and Çiçek and Sungur } \\
\text { Birecikligil (2016). } \\
\text { The type locality of the species is Abkhazia, Black Sea basin. S. turcicus and S. agdamicus are inhabiting Kura and Aras } \\
\text { drainages (Bayçelebi 2019). }\end{array}$ \\
\hline 20 & $\begin{array}{l}\text { Stenodus leucichthys } \\
\text { Abdurakhmanov, } \\
1950\end{array}$ & $\begin{array}{l}\text { The species was erroneously reported to be in the upper Aras drainage by Fricke et al. (2007), followed by Çiçek et al. } \\
(2015) \text { and Çiçek and Sungur Birecikligil (2016). Poursaeid and Falahatkar (2012) discussed the distribution of the } \\
\text { species in the Caspian Sea basin, however, they did not mention the occurrence of the species in the upper Kura and } \\
\text { Aras rivers. }\end{array}$ \\
\hline
\end{tabular}

Examined material. FFR 1812, Kura River at Yalnızçam, 41.0709N, 42.4844E. -FFR 1815, Stream Çakır, 3 km south of Çakıldere, Kura drainage, 40.9669N, 42.5861E. -FFR 1606, Stream Ölçek at Ölçek, Kura drainage, $41.1340 \mathrm{~N}, 42.8560 \mathrm{E}$. -FFR 1608, Stream Doğruyol at Doğruyol, Aras drainage, 41.0620N, 43.3450E. -FFR 1819, Lake Çıldır, Aras drainage, 41.0449N, 43.2804E.
Not preserved, Stream Fehmiharabesi at Akçalar, Aras drainage, 40.7723N, 43.2959E. -FFR 1603, Steam Susuz at Susuz, Aras drainage, 40.7806N, 43.1411E. Not preserved, Stream Kars at campus of Kafkas University, Aras drainage, 40.5814N, 43.0591E. -FFR 1607, Stream Maksutçuk west of Dikme, Aras drainage, 40.5160N, 42.9510E. -FFR 1604, Stream Kekeç at Selim, Aras 


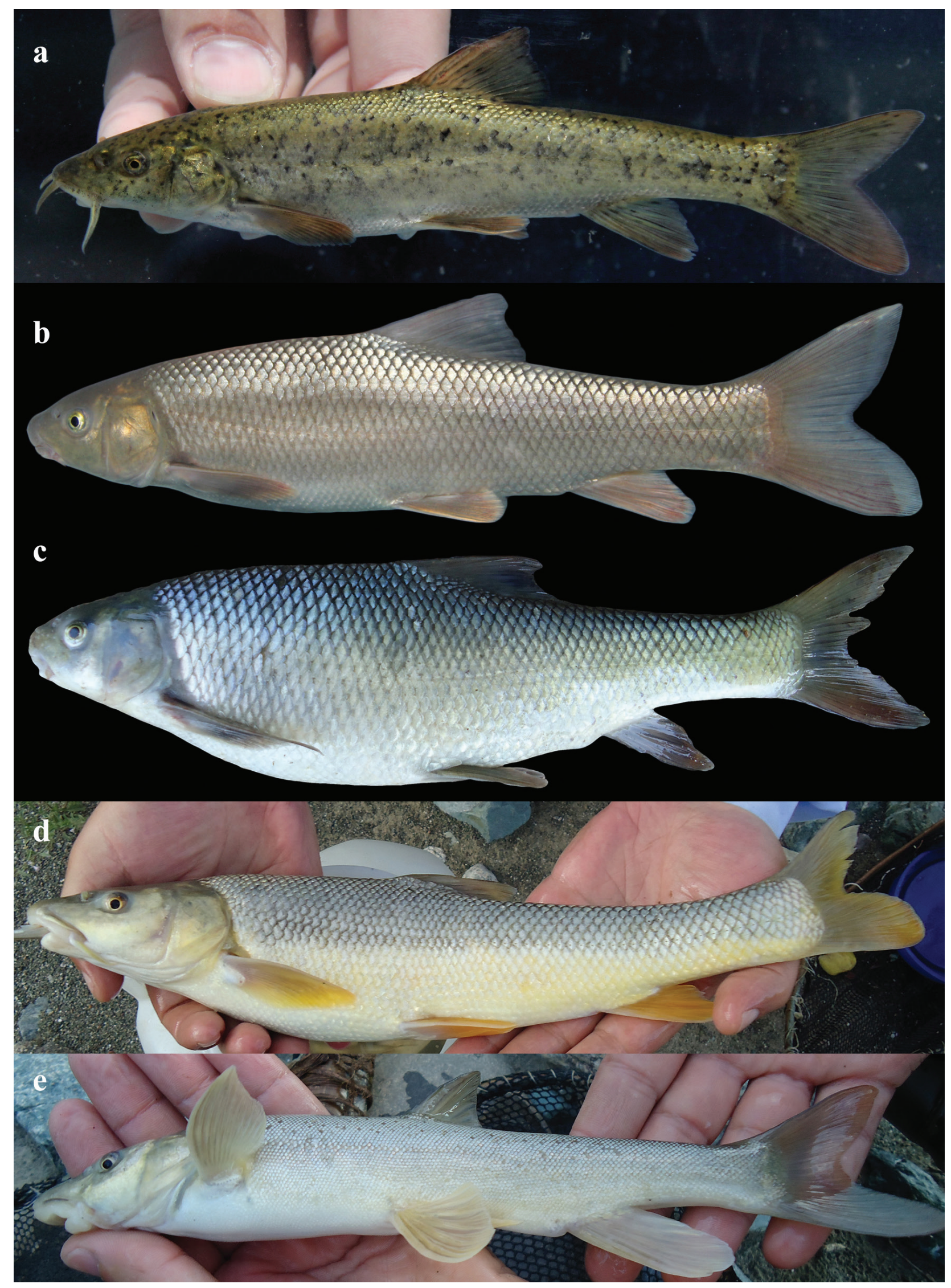

Figure 2. Native Cyprinid species collected in the area, a, Barbus cyri from Kura River at Yalnızçam; b, Capoeta capoeta from stream Kars, Aras; c, Capoeta kaput from B-20 canal, Aras; d, Luciobarbus capito from stream Gaziler, Aras; e, Luciobarbus mursa from stream Gaziler, Aras. 
drainage, 40.4715N, 42.8005E. -FFR 1814, Stream Boyalı at Boyalı, Aras drainage, 40.4478N, 42.5833E. -FFR 1800, Stream Kızılçubuk at Kızılçubuk, Aras drainage, 40.3736N, 42.5366E. -FFR 1945, Aras River at Köprüçay, 39.9699N, 41.8883E. -FFR 1821, Stream Digor at Digor, Aras drainage, 40.3731N, 43.4271E. Not preserved, Aras River $4 \mathrm{~km}$ west of Donand1, 40.1097N, 43.4349E. Not preserved, Lake Balık at Tanyolu, Aras drainage, 39.7451N, 43.5385E. -FFR 1816, Stream Sarısu West of Doğubeyazıt, Aras drainage, 39.5409N, 44.0044E.

Distribution in the area. Widespread in tributaries of Kura and Aras rivers.

\section{Capoeta kaput Levin, Prokofiev \& Roubenyan, 2019} Fig. 2c

Common / local names. Blue Aras scraper* / Mavi Aras sirazi*.

IUCN status. Not evaluated (NE).

Examined material. FFR 1835, B-20 canal at Aralı, Aras drainage, $39.8936 \mathrm{~N}, 44.5256 \mathrm{E}$.

Distribution in the area. Capoeta kaput was found only in B-20 canal. The species was described from Aras River in Armenia (Levin et al. 2019). Recently, it has been recorded from Aras River in Turkey (Kaya 2019).

\section{Carassius gibelio (Bloch, 1782)}

Fig. 3a

Common / local names. Prussian carp / Havuz balığg1.

IUCN status. Not evaluated (NE).

Examined material. Not preserved, Kura River at Yalnızçam, 41.0709N, 42.4844E. -FFR 2217, Lake Çıldır, Aras drainage, 41.0449N, 43.2804E. -FFR 2216, Stream Gaziler, 2 km west of Donand1, Aras drainage, 40.1097N, 43.4349E.

Distribution in the area. The species was found in Lake Çıldır and streams Gaziler and Yalnızçam. It was also reported from Lake Aktaş and Stream Sarısu (Çiçek and Sungur Birecikligil 2016).

\section{Cyprinus carpio Linnaeus, 1758}

Fig. $3 b$

Common / local names. Common carp / Sazan.

IUCN status. Vulnerable (VU).
Examined material. FFR 2749, Lake Çıldır, Aras drainage, 41.0449N, 43.2804E. -FFR 2751, Stream Gaziler, 2 $\mathrm{km}$ west of Donand1, Aras drainage, 40.1097N, 43.4349E. Not preserved, Lake Balı at Tanyolu, Aras drainage, 39.7451N, 43.5385E. -FFR 2744, B-20 canal at Aralık, Aras drainage, $39.8936 \mathrm{~N}, 44.5256 \mathrm{E}$.

Distribution in the area. The species was found in stream Gaziler, B-20 canal and Lake Çıldır.

Note. Both native and introduced Cyprinus carpio inhabit Lake Çıldır. The native common carp is very distinct due to its slenderer body and yellow general body color (Fig. $3 \mathrm{~b})$. When compared to the introduced one, the native $C$. caripo is very popular and economically valuable among the local people in the area.

\section{Luciobarbus capito (Güldenstädt, 1773)}

Fig. 2d

Common / local names. Bulatmai barbel / Hazar tilkiburunu*.

IUCN status. Vulnerable (VU).

Examined material. FFR 355, Stream Gaziler, 2 km west of Donand1, Aras drainage, 40.1097N, 43.4349E.

Distribution in the area. The species was found only in stream Gaziler.

Luciobarbus mursa (Güldenstaedt, 1773)

Fig. 2e

Common / local names. Mursa / Murzu.

IUCN status. Least concern (LC).

Examined material. FFR 334, Stream Gaziler, 2 km west of Donand1, Aras drainage, 40.1097N, 43.4349E.

Distribution in the area. The species was found only in stream Gaziler.

Family Acheilognathidae Bleeker, 1863

Rhodeus amarus (Bloch, 1782)

Fig. 3c

Common / local names. European bitterling / Acıbalık.

IUCN status. Least concern (LC).

Examined material. FFR 3524, B-20 canal at Aralık, Aras drainage, $39.8936 \mathrm{~N}, 44.5256 \mathrm{E}$. 


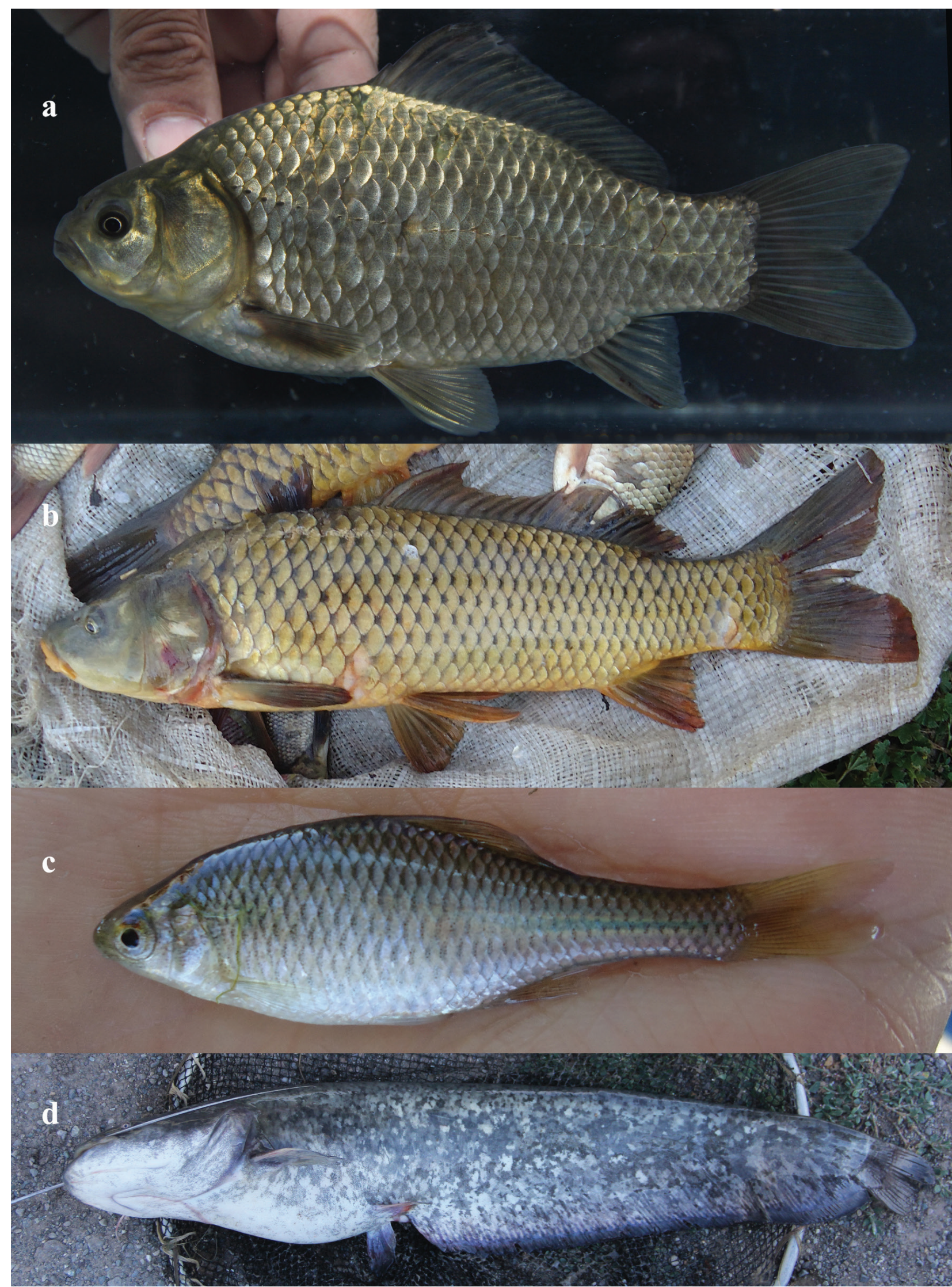

Figure 3. Acheilognathidae, Siluridae and two Cyprinid species collected in the area, a, Carassius gibelio from Kura River at Yalnızçam; b, Cyprinus carpio from Lake Çıldır, Aras; c, Rhodeus amarus from B-20 canal, Aras; d, Silurus glanis from stream Kars, Aras. 
Distribution in the area. The species is recorded in B-20 canal located very close to the border with Armenia. Rhodeus amarus was recorded from Lake Urmia and Caspian Sea basins in Iran (Derzhavin 1934; Holčík and Oláh 1992; Kiabi et al. 1999; Abbasi et al. 1999; Abdoli, 2000; Ghasemi et al. 2015; Coad 2018). Probably it also occurs in Aras River in Armenia (Pipoyan, 1996).

Family Gobionidae Bleeker, 1863

\section{Gobio artvinicus Turan, Japoshvili, Aksu \& Bektaş, 2016}

Fig. 4d

Common / local names. Artvin gudgeon* / Artvin Derekayası*.

IUCN status. Not evaluated (NE).

Examined material. FFR 5923, B-20 canal at Aralik, Aras drainage, $39.8936 \mathrm{~N}, 44.5256 \mathrm{E}$.

Distribution in the area. The species has been known to occur in Çoruh River and has not been recorded in any another place, including Kura and Aras river drainages, despite intensive field work. However, it has recently been declared that G. artvinicus translocated to the Caspian Sea basin and occurs in Armenia, Azerbaijan and Georgia (Kuljanishvili et al. 2020). In the present study also, some specimens belonging to genus Gobio were observed and they are superficially similar to $G$. artvinicus.

\section{Pseudorasbora parva (Temminck \& Schlegel, 1842)} Fig. 4c

Common / local names. Stone moroko / Çakıl balığı.

IUCN status. Least concern (LC).

Examined material. Not preserved, Lake Aktaş at Kenarbel, Kura drainage, 41.1917N, 43.1737E.

Distribution in the area. The species was recorded only from Lake Aktaş. It was also recorded in Lake Çıldır (Çiçek and Sungur Birecikligil 2016).

\section{Romanogobio macropterus (Kamensky, 1901) Fig. $4 \mathrm{~d}$}

Common / local names. Kura gudgeon / Kura Derekayası*.

IUCN status. Least concern (LC).
Examined material. FFR 5977, Kura River at Yalnızçam, 41.0709N, 42.4844E. -FFR 5922, Stream Çakır, 3 km south of Çakıldere, Kura drainage, 40.9669N, 42.5861E. Not preserved, Stream Kars at campus of Kafkas University, Aras drainage, 40.5814N, 43.0591E. -FFR 5969, Aras River at Köprüçay, 39.9699N, 41.8883E.

Distribution in the area. Kura and Aras River drainages in northeastern Turkey.

Remarks. The type locality of the species is the Caucasus. The Kura population was identified as $R$. macropterus. However, we observed some morphological differences between Kura and Aras populations obtained in this study. The Aras population has a slenderer body and caudal peduncle than R. macropterus from Kura (Fig. 4d, 4e). Therefore, we encourage detailed morphologic and molecular research including the Kura, Aras and Urmia populations to clarify the taxonomic position of the Aras population.

Family Leuciscidae Bonaparte, 1835

\section{Acanthobrama microlepis (De Filippi, 1863)}

Fig. 5a

Common / local names. Blackbrow bream / Kura akçapağ 1 *.

IUCN status. Least concern (LC).

Examined material. FFR 1172, Stream Çakır, $3 \mathrm{~km}$ south of Çakıldere, Kura drainage, 40.9669N, 42.5861E. -FFR 1167, Stream Ölçek at Ölçek, Kura drainage, 41.1340N, 42.8560E. -FFR 1170, Stream Doğruyol at Doğruyol, Aras drainage, $41.0620 \mathrm{~N}, 43.3450 \mathrm{E}$. -FFR 1196, Aras River at Köprüçay, 39.9699N, 41.8883E. Not preserved, Aras River 4 km west of Donand1, 40.1097N, 43.4349E. -FFR 1165, Stream Gaziler, 2 km west of Donand1, Aras drainage, $40.1097 \mathrm{~N}, 43.4349 \mathrm{E}$.

Distribution in the area. Kura and Aras River drainages in northeastern Turkey.

Note. Both molecular (Perea et al. 2010) and morphologic (Küçük et al. 2014) studies suggested the synonymization of the genus Acanthalburnus with Acanthobrama. Therefore, this species is now under the genus Acanthobrama.

\section{Alburnoides eichwaldii De Filippi, 1863}

Fig. 6a

Common / local names. Kura spirlin* / Kura noktalı incisi*.

IUCN status. Least concern (LC). 


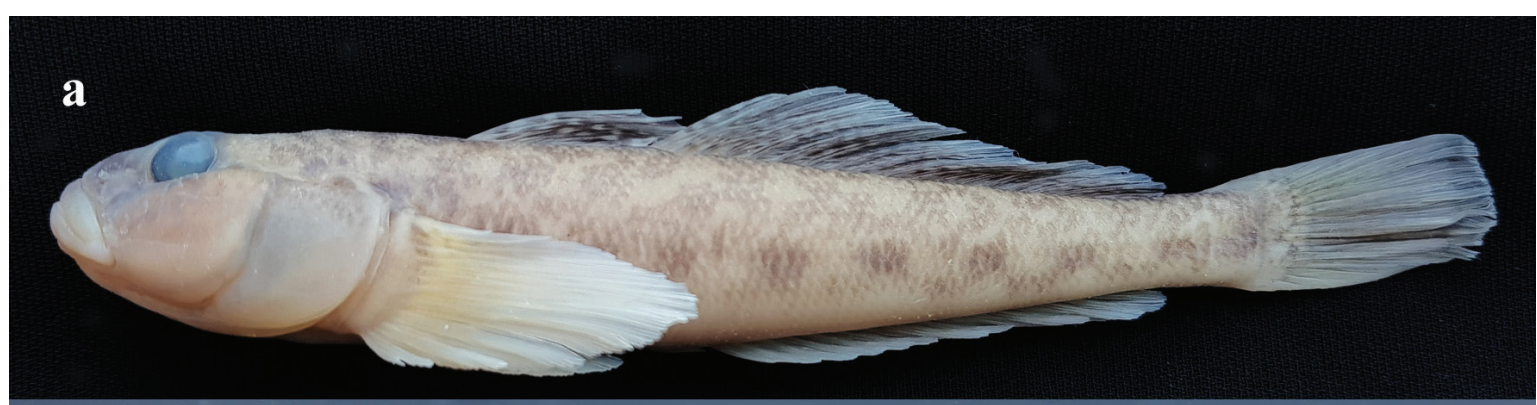

b
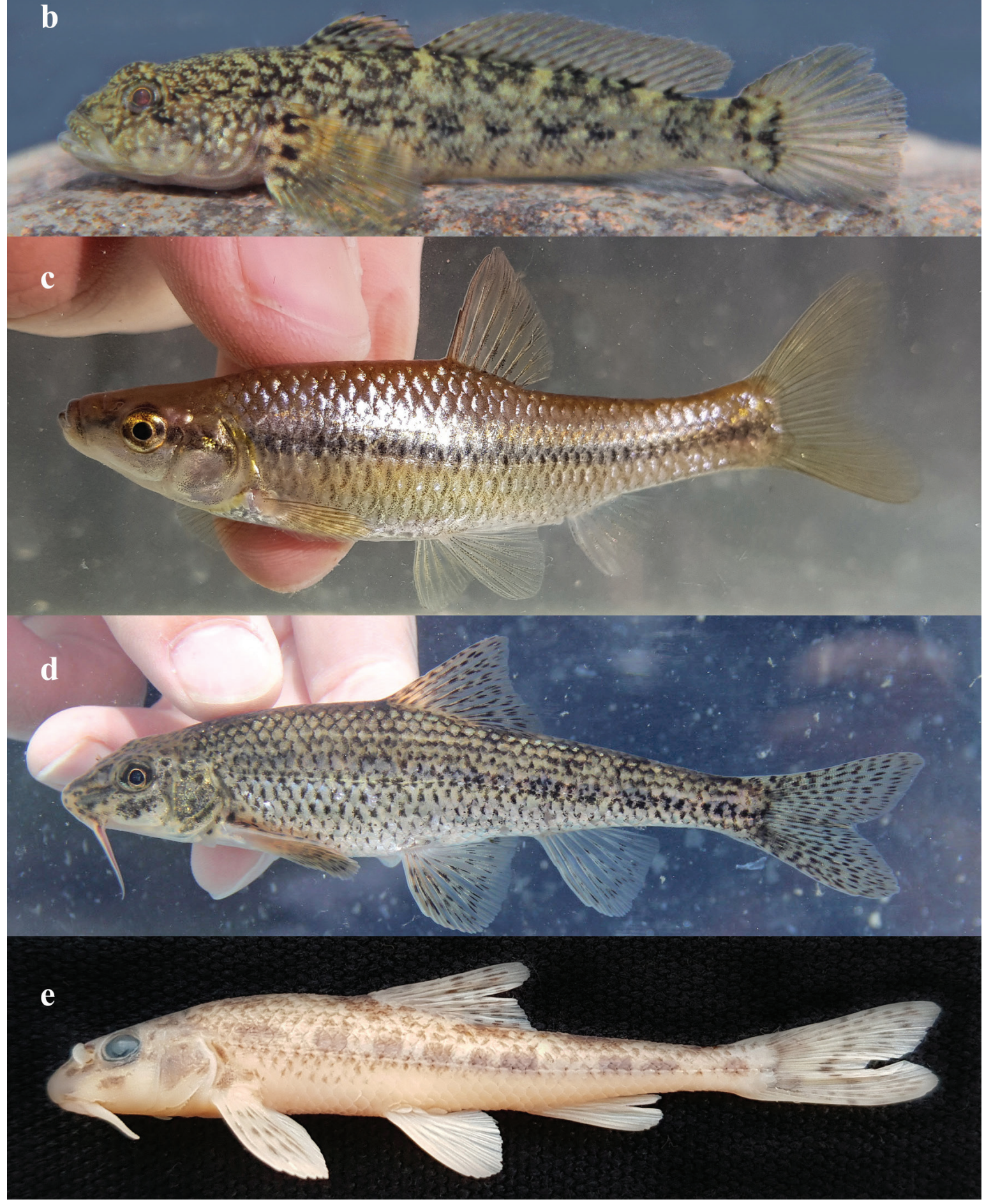

Figure 4. Gobiidae and Gobionidae species collected in the area, a, Neogobius fluviatilis from B-20 canal, Aras; b, Ponticola cyrius from Kura River at Yalnızçam; c, Pseudorasbora parva from Lake Aktaş, Kura; d, Romanogobio macropterus from Kura River at Yalnızçam; e, Romanogobio macropterus from Kura River at Yalnızçam. 

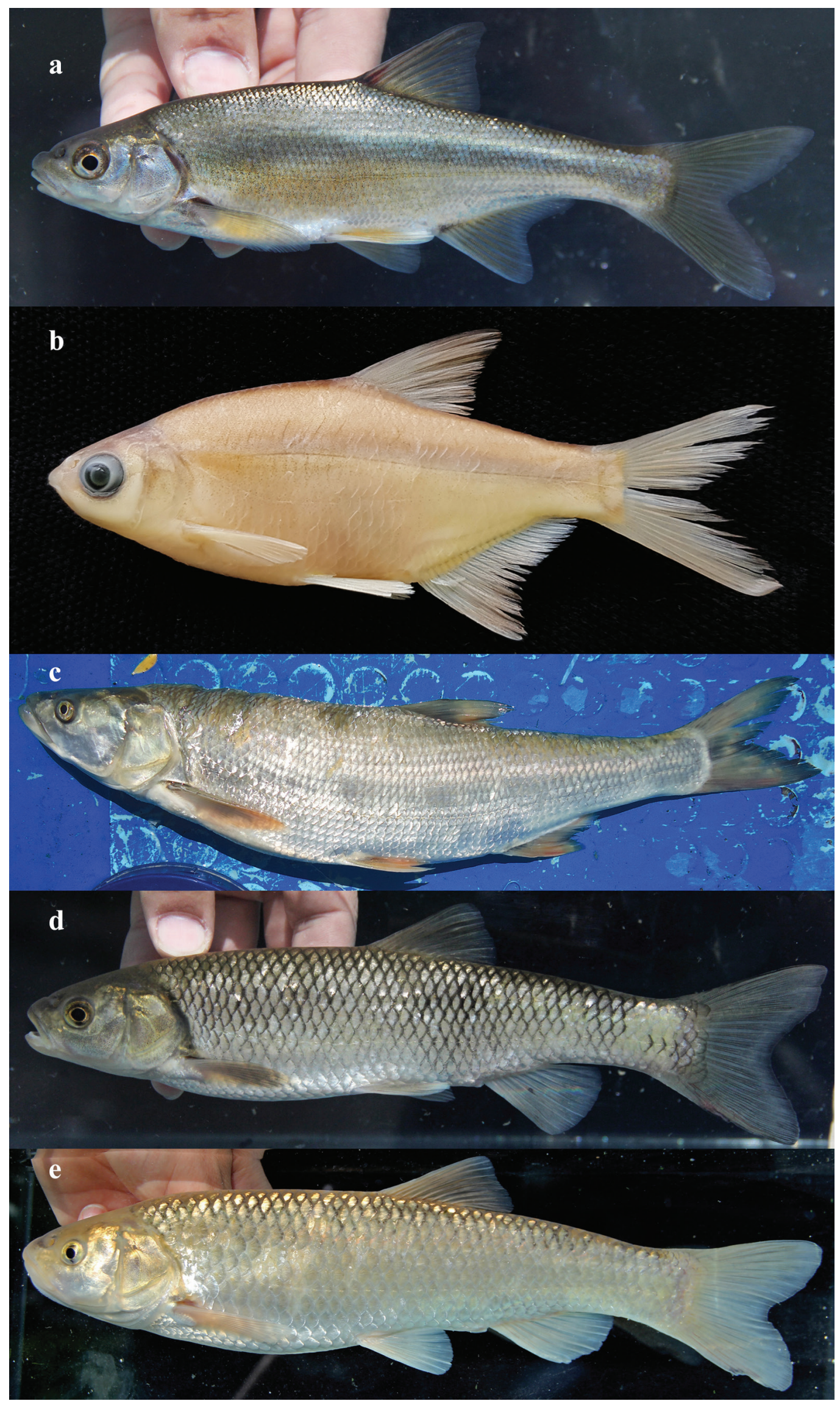

Figure 5. Some Leuciscidae species collected in the area, a, Acanthobrama microlepis from Kura River at Yalnızçam; b, Blicca bjoerkna from B-20 canal, Aras; c, Leuciscus aspius from Lake Çıldır, Aras; d, Squalius agdamicus from Kura River at Yalnızçam; e, Squalius turcicus, from stream Fehmiharabesi, Aras. 


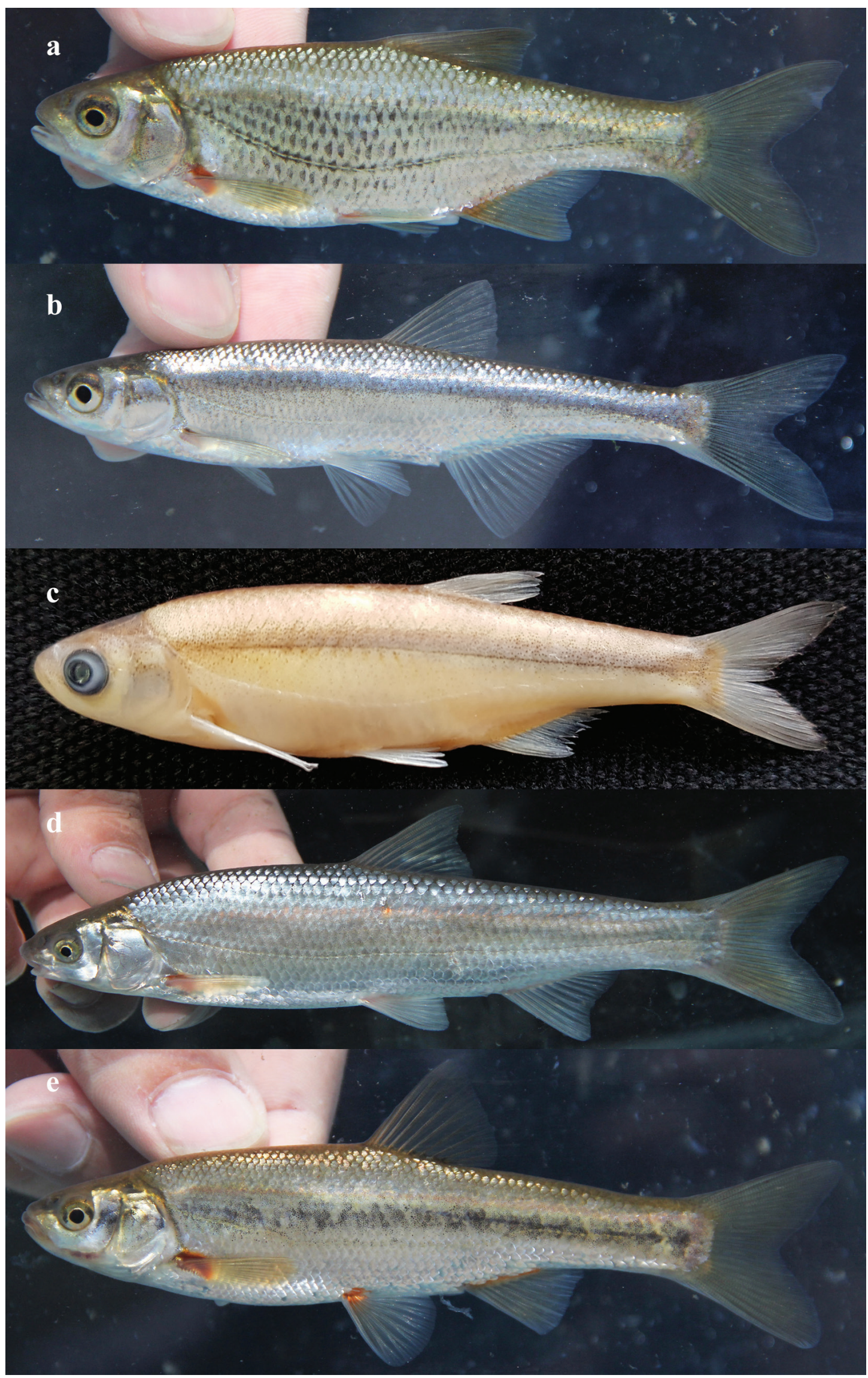

Figure 6. Some Leuciscidae species collected in the area, a, Alburnoides eichwaldii from Kura River at Yalnızçam; b, Alburnus filippi from Kura River at Yalnızçam; c, Alburnus hohenackeri from B-20 canal, Aras; d, Chondrostoma cyri from stream Kars, Aras; e, Leucalburnus satunini from Kura River at Yalnızçam. 
Examined material. FFR 1013, Stream Karaman at Aşıkzülal, Kura drainage, 41.4413N, 42.6591E. Not preserved, Stream Çöt Suyu South of Çatköy, Kura drainage, 41.2998N, 42.7087E. -FFR 1089, Kura River at Yalnız̧̧am, 41.0709N, 42.4844E. -FFR 1091, Stream Çakır, $3 \mathrm{~km}$ south of Çakıldere, Kura drainage, 40.9669N, 42.5861E. -FFR 1047, Stream Ölçek at Ölçek, Kura drainage, 41.1340N, 42.8560E. -FFR 1085, Lake Çıldır, Aras drainage, 41.0449N, 43.2804E. Not preserved, Stream Fehmiharabesi at Akçalar, Aras drainage, $40.7723 \mathrm{~N}, 43.2959 \mathrm{E}$. -FFR 1015, Stream Maksutçuk west of Dikme, Aras drainage, 40.5160N, 42.9510E. -FFR 1019, Steam Susuz at Susuz, Aras drainage, 40.7806N, 43.1411E. Not preserved, Stream Kars at campus of Kafkas University, Aras drainage, 40.5814N, 43.0591E. -FFR 1088, Stream Kekeç at Selim, Aras drainage, 40.4715N, 42.8005E. -FFR 1086, Stream Boyall at Boyal1, Aras drainage, 40.4478N, 42.5833E. -FFR 1082, Stream Kızılçubuk at Kızılçubuk, Aras drainage, 40.3736N, 42.5366E. -FFR 7012, Aras River at Köprüçay, 39.9699N, 41.8883E. -FFR 1093, Stream Digor at Digor, Aras drainage, 40.3731N, 43.4271E. -FFR 7020, Aras River 4 km west of Donand1, 40.1097N, 43.4349E. -FFR 1087, Stream Gaziler, 2 km west of Donand1, Aras drainage, 40.1097N, 43.4349E. -FFR 7011, Stream Aktarla at Aktarla, a southern drainage of Lake Balık, 39.7373N, 43.5815E. -FFR 1090, B-20 canal at Aralık, Aras drainage, $39.8936 \mathrm{~N}, 44.5256 \mathrm{E}$.

Distribution in the area. Widespread in tributaries of Kura-Aras rivers.

\author{
Alburnus filippii Kessler, 1877 \\ Fig. $6 \mathrm{~b}$
}

Common / local names. Kura bleak / Kura incisi*.

IUCN status. Least concern (LC).

Examined material. FFR 4687, Kura River at Yalnızçam, 41.0709N, 42.4844E. -FFR 942, Stream Çakır, $3 \mathrm{~km}$ south of Çakıldere, Kura drainage, 40.9669N, 42.5861E. -FFR 943, Stream Ölçek at Ölçek, Kura drainage, 41.1340N, 42.8560E. -FFR 936, Lake Çıldır, Aras drainage, 41.0449N, 43.2804E. -FFR 4688, Stream Büyük Çayır at Arpaçay, Aras drainage, 40.8431N, 43.3222E. -FFR 4685, Stream Fehmiharabesi at Akçalar, Aras drainage, 40.7723N, 43.2959E. -FFR 872, Steam Susuz at Susuz, Aras drainage, 40.7806N, 43.1411E. FFR 4686, Stream Kars at campus of Kafkas University, Aras drainage, 40.5814N, 43.0591E. -FFR, 899, Stream Maksutçuk west of Dikme, Aras drainage, 40.5160N, 42.9510E. -FFR 940, Stream Kekeç at Selim, Aras drainage, 40.4715N, 42.8005E. -FFR 939, Stream Boyalı at Boyal1, Aras drainage, 40.4478N, 42.5833E. -FFR 4654, Aras River at Köprüçay, 39.9699N, 41.8883E. FFR 948, Stream Gaziler, 2 km west of Donand1, Aras drainage, 40.1097N, 43.4349E. -FFR 947, B-20 canal at Aralık, Aras drainage, 39.8936N, 44.5256E. -FFR 820, Stream Doğruyol at Doğruyol, Aras drainage, $41.0620 \mathrm{~N}$, 43.3450E.

Distribution in the area. Widespread in tributaries of Kura-Aras rivers.

\section{Alburnus hohenackeri Kessler, 1877}

Fig. 6c

Common / local names. Caspian bleak / Hazar Denizi incisi*.

IUCN status. Least concern (LC).

Examined material. FFR 4699, B-20 canal at Aralık, Aras drainage, $39.8936 \mathrm{~N}, 44.5256 \mathrm{E}$.

Distribution in the area. It was recorded from B-20 canal, Aras River.

Note. The occurrence of the species in the region has been reported by earlier studies based on estimates (Fricke et al. 2007; Çiçek et al. 2015). A. hohenackeri was documented with the materials observed for the first time in the B-20 canal, Turkey. We observed two syntopic shemeya from the B-20 canal. Alburnus hohenackeri is easily distinguished from $A$. flippii by having a stout and deep body as well as large scales (Fig. 6b, c).

\section{Blicca bjoerkna (Linnaeus, 1758)} Fig. $5 b$

Common / local names. White bream / Tahta balığı.

IUCN status. Least concern (LC).

Examined material. FFR 2425, B-20 canal at Aralık, Aras drainage, $39.8936 \mathrm{~N}, 44.5256 \mathrm{E}$

Distribution in the area. It was first recorded from B-20 canal, Aras River.

\section{Chondrostoma cyri Kessler, 1877}

Fig. 6d

Common / local names. Colchic nase / Kura kababurunu*.

IUCN status. Least concern (LC).

Examined material. FFR 2040, Stream Çakır, $3 \mathrm{~km}$ south of Çakıldere, Kura drainage, 40.9669N, 42.5861E. -FFR 2041, Lake Çıldır, Aras drainage, 41.0449N, 43.2804E. 
-FFR 2030, Stream Kars at campus of Kafkas University, Aras drainage, 40.5814N, 43.0591E. -FFR 2042, B-20 canal at Aralık, Aras drainage, 39.8936N, 44.5256E.

Distribution in the area. Widespread in tributaries of Kura-Aras rivers.

\section{Leucalburnus satunini (Berg, 1910)}

Fig. 6e

Common / local names. White Kura bleak / Satunin incisi.

IUCN status. Least concern (LC).

Examined material. FFR 2467, Kura River at Yalnızçam, 41.0709N, 42.4844E. -FFR 2464, Stream Çakır, $3 \mathrm{~km}$ south of Çakıldere, Kura drainage, 40.9669N, 42.5861E. -FFR 2465, Stream Ölçek at Ölçek, Kura drainage, $41.1340 \mathrm{~N}, 42.8560 \mathrm{E}$.

Distribution in the area. Known from upper Kura River drainage. Endemic to the area.

\section{Leuciscus aspius (Linnaeus, 1758)}

Fig. 5c

Common / local names. Asp / Kocaağız balığı.

IUCN status. Least concern (LC).

Examined material. FFR 2441, Lake Çıldır, Aras drainage, $41.0449 \mathrm{~N}, 43.2804 \mathrm{E}$.

Distribution in the area. Aras River drainage. Recorded from in Lake Çıldır.

\section{Squalius agdamicus Kamensky, 1901}

Fig. 5d

Common / local names. Agdam dace / Agdam tatlisu kefali*.

IUCN status. Not evaluated (NE).

Examined material. FFR 638, Stream Açıkyazı at Kazlıköy, Kura drainage, 41.1443N, 42.5908E. -FFR 687, Kura River at Yalnızçam, 41.0709N, 42.4844E. -FFR 684, Stream Çakır, $3 \mathrm{~km}$ south of Çakıldere, Kura drainage, 40.9669N, 42.5861E. -FFR 684, Stream Ölçek at Ölçek, Kura drainage, 41.1340N, 42.8560E.

Distribution in the area. Kura River drainage in northeast Anatolia. The species has been known from lower Kura. Recently, it was recorded from Kura River in Turkey (Bayçelebi 2019).
Squalius turcicus De Filippi, 1865

Fig. 5e

Common / local names. Kura chub* / Kura tatlı su kefali*.

IUCN status. Least concern (LC).

Examined material. FFR 692, Lake Çıldır, Aras drainage, 41.0449N, 43.2804E. Not preserved, Stream Fehmiharabesi at Akçalar, Aras drainage, 40.7723N, 43.2959E. Not preserved, Stream Kars at campus of Kafkas University, Aras drainage, 40.5814N, 43.0591E. -FFR 681, Stream Kekeç at Selim, Aras drainage, 40.4715N, 42.8005E. -FFR 689, Stream Boyalı at Boyal1, Aras drainage, 40.4478N, 42.5833E. -FFR 634, Stream Kars at Çatak, Aras drainage, 40.4016N, 42.6783E. -FFR 6273, Aras River at Köprüçay, 39.9699N, 41.8883E. -FFR 690, Stream Digor at Digor, Aras drainage, 40.3731N, 43.4271E. not preserved, Lake Balık at Tanyolu, Aras drainage, 39.7451N, 43.5385E. -FFR 683, B-20 canal at Aralık, Aras drainage, $39.8936 \mathrm{~N}, 44.5256 \mathrm{E}$.

Distribution in the area. Widespread in Aras River drainage.

Family Cobitidae Swainson, 1838

Cobitis saniae Eagderi, Jouladeh-Roudbar, Jalili, Sayyadzadeh \& Esmaeili, 2017

Fig. 7e

Common / local names. Caspian spined loach* / Hazar taşemeni*.

IUCN status. Not evaluated (NE).

Examined material. Not preserved, Stream Kars at campus of Kafkas University, Aras drainage, 40.5814N, 43.0591E. -FFR 5500, Stream Kekeç at Selim, Aras drainage, 40.4715N, 42.8005E. -FFR 5549, Aras River at Köprüçay, 39.9699N, 41.8883E.

Distribution in the area. Recently recorded from streams Selim and Kars, Aras River drainage (Freyhof et al. 2018).

Sabanejewia aurata (De Filippi, 1863)

Fig. 7d

Common / local names. Golden Spined Loach / Altın dikenli çöpçü balığı*.

IUCN status. Least concern (LC).

Examined material. FFR 5514, Stream Çakır, $3 \mathrm{~km}$ south of Çakıldere, Kura drainage, 40.9669N, 42.5861E. -FFR 


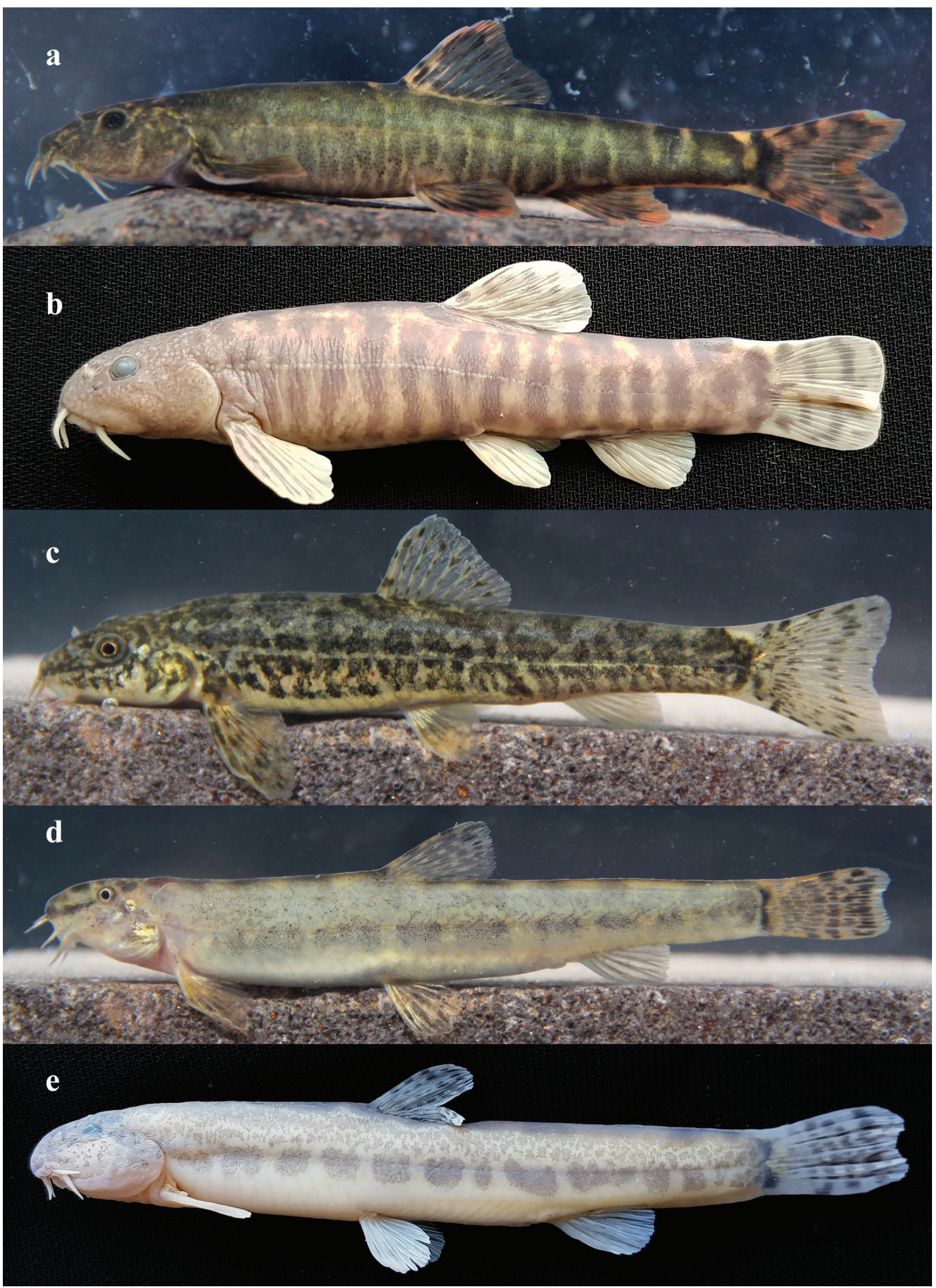

Figure 7. Nemacheilidae and Cobitidae species collected in the area, a, Oxynoemacheilus brandtii from Kura River at Yalnızçam; b, O. cyri from stream Çakır, Kura; c, O. veyselorum from stream Kars, Aras; d, Sabanejewia aurata from stream Kars, Aras; e, Cobitis saniae from Aras River at Köprüçay. 
5513, Stream Ölçek at Ölçek, Kura drainage, 41.1340N, 42.8560E. -FFR 5559, Stream Fehmiharabesi at Akçalar, Aras drainage, $40.7723 \mathrm{~N}, 43.2959 \mathrm{E}$.

Distribution in the area. The species is known from Aras River drainage.

\section{Family Nemacheilidae Regan, 1911}

Oxynoemacheilus brandtii (Kessler, 1877)

Fig. $7 \mathrm{a}$

Common / local names. Kura loach* / Aras çöpçü balığı*.

IUCN status. Least concern (LC).

Examined material. FFR 1460, Stream Ölçek at Ölçek, Kura drainage, 41.1340N, 42.8560E. -FFR 15551, Stream Büyük Çayır at Arpaçay, Aras drainage, 40.8431N, 43.3222E. -FFR 15549, Stream Fehmiharabesi at Akçalar, Aras drainage, 40.7723N, 43.2959E. -FFR 1350, Stream Kekeç at Selim, Aras drainage, 40.4715N, 42.8005E. -FFR 1382, Stream Maksutçuk west of Dikme, Aras drainage, 40.5160N, 42.9510E. -FFR 1427, Stream Digor at Digor, Aras drainage, 40.3731N, 43.4271E. -FFR 1422, Stream Gaziler, 2 km west of Donand1, Aras drainage, 40.1097N, 43.4349E.

Distribution in the area. The species is widespread in Kura and Aras river drainages.

\section{Oxynoemacheilus cyri (Berg, 1910)}

Fig. 7b

Common / local names. Göle loach / Göle çöpçü balığı*.

IUCN status. Least concern (LC).

Examined material. FFR 1426, Stream Çakır, $3 \mathrm{~km}$ south of Çakı1dere, Kura drainage, 40.9669N, 42.5861E.

Distribution in the area. The species is endemic to the upper reaches of the Kura River drainage.

\section{Oxynoemacheilus veyselorum Çiçek, Eagderi \& Sungur, 2018 \\ Fig. 7c}

Common / local names. Aras loach* / Aras çöpçü balığı*.

IUCN status. Not evaluated (NE).

Examined material. FFR 3621, Stream Doğruyol at Doğruyol, Aras drainage, 41.0620N, 43.3450E. -FFR 15550, Stream Büyük Çayır at Arpaçay, Aras drainage, 40.8431N, 43.3222E. -FFR 15548, Stream Fehmiharabesi at Akçalar, Aras drainage, 40.7723N, 43.2959E. Not preserved, Stream Kars at campus of Kafkas University, Aras drainage, 40.5814N, 43.0591E. -FFR 1352, Stream Kekeç at Selim, Aras drainage, 40.4715N, 42.8005E. -FFR 3622, Stream Boyalı at Boyalı, Aras drainage, 40.4478N, 42.5833E. -FFR 3623, Stream Kızılçubuk at Kızılçubuk, Aras drainage, 40.3736N, 42.5366E. -FFR 1597, Stream Digor at Digor, Aras drainage, 40.3731N, 43.4271E.

Distribution in the area. Aras River drainages in northeastern Anatolia. The species recently described from stream Bozkuș (40³7'03.7"N, 4247'04.9"E), a drainage of Aras River (Çiçek et al. 2018). Here it was recorded from eight additional localities (streams Doğruyol, Kekeç, Kars, Fehmiharabesi, Boyalı, Digor, Kızılçubuk and Büyük Çayır) in tributaries of Aras River (Table 1).

Notes on nomenclature. Çiçek et al. (2018) described Oxynoemacheilus veyseli in honor of Veysel Çiçek. The epithet stands for two persons as father and son of the first author. In Article 31.1.2. of the International Code for Zoological Nomenclature (ICZN 1999), it is clearly indicated that: "A species-group name, if a noun in the genitive case (see Article 11.9.1.3) formed directly from a modern personal name, is to be formed by adding to the stem of that name $-i$ if the personal name is that of a man, -orum if of men or of man (men) and woman (women) together, -ae if of a woman, and -arum if of women; the stem of such a name is determined by the action of the original author when forming the genitive." Therefore, the name of the species is treated here as Oxynoemacheilus veyselorum.

Family Siluridae Rafinesque, 1815

Silurus glanis Linnaeus, 1758

Fig. 3d

Common / local names. Wels catfish / Yayın.

IUCN status. Least concern (LC).

Examined material. Not preserved, Stream Kars at campus of Kafkas University, Aras drainage, 40.5814N, 43.0591E. -FFR 2704, B-20 canal at Aralık, Aras drainage, $39.8936 \mathrm{~N}, 44.5256 \mathrm{E}$.

Distribution in the area. The species is found from the stream Kars in this study.

Family Salmonidae Jarocki or Schinz, 1822

Oncorhynchus mykiss (Walbaum, 1792)

Fig. 8a

Common / local names. Rainbow trout / Gökkuşağ 1 alabalı̆̆ 1 . 
IUCN status. Not evaluated (NE).

Examined material. Not preserved, Lake Çıldır, Aras drainage, 41.0449N, 43.2804E.

Distribution in the area. The species was recorded from Lake Çıldır.

Salmo caspius Kessler, 1877

Fig. $8 b$

Common / local names. Caspian trout / Hazar alas1*.

IUCN status. Not evaluated (NE).

Examined material. Not preserved, Stream Çöt Suyu South of Çatköy, Kura drainage, 41.2998N, 42.7087E. FFR 1129, Stream Kınavur at Çataldere, Kura drainage, 41.1976N, 42.6135E. -FFR 3164, Stream Toros, 4 km south of Çimenkaya, Kura drainage, $41.1115 \mathrm{~N}, 42.4468 \mathrm{E}$. -FFR 3135, Stream Çakır, 3 km south of Çakıldere, Kura drainage, $40.9669 \mathrm{~N}, 42.5861 \mathrm{E}$.

Distribution in the area. Kura River drainage.

\section{Salmo aff. caspius Kessler, 1877}

Fig. 8c

Common / local names. Aras trout / Aras alası*.

Examined material. FFR 3122, Stream Tahtakaya at Kirkpınar, Aras drainage, 40.8539N, 43.0188E. FFR 3114, Stream Kayalık at Kayalık, Aras drainage, 40.8201N, 43.1268E. -FFR 3144, Stream İncilipınar at İncilipınar, Aras drainage, 40.8211N, 43.0751E.

Distribution in the area. Aras River drainage.

Remarks. The species is morphologically most similar to $S$. caspius. However, it seems that there are some significant differences between Kura and Aras populations. A detailed morphological examination is needed to clear the taxonomic position of salmonids in Aras drainage.

Salmo cf. ciscaucasicus Dorofeeva, 1967

Fig. 8d

Common / local names. Caucasian trout* / Kafkas alası*.

Examined material. FFR 3229, Stream Keklik 6 km southeast of Sarıkamış, Aras drainage, 40.2955N, 42.6565E.

Distribution in the area. Aras River drainage.
Remarks. The species is morphologically similar to $S$. ciscaucasicus, however, more comparison materials from upper Aras and Keyranchay River (its type locality) are needed to clear the taxonomic position of Aras populations. For the first observation by limited samples identified here as Salmo cf. ciscaucasicus differ from $S$. caspius from Kura drainages by having a brownish general body color (vs. grayish), irregular black and red spots (vs. circular). On the other hand, the samples we obtained have grayish general body color, numerous black spots on the body, irregularly shaped, small to medium, maxilla reaching slightly beyond the eye, adipose-fin of moderate size, not reaching caudal-fin base. These features overlap with the original description of Dorofeyeva (1967) and the figure and description of Kottelat \& Freyhof (2007). Therefore, we consider that species closely related to $S$. ciscaucasicus, and we encourage further research to clarify the trout taxonomy in the area.

Family Gobiidae Cuvier, 1816

Neogobius fluviatilis (Pallas, 1814)

Fig. 4a

Common / local names. Monkey goby / Tatlısu kayası.

IUCN status. Least concern (LC).

Examined material. FFR 2636, B-20 canal at Aralık, Aras drainage, $39.8936 \mathrm{~N}, 44.5256 \mathrm{E}$.

Distribution in the area. The species native for the Caspian Sea basin (Pinchuk et al. 2003). The species was recorded from B-20 canal. It is the first record for the Turkish Aras River.

Ponticola cyrius (Kessler, 1874)

Fig. $4 \mathrm{~b}$

Common / local names. Kura goby / Kura kayası*.

IUCN status. Least concern (LC).

Examined material. FFR 2620, Stream Karaman at Aşıkzülal, Kura drainage, 41.4413N, 42.6591E. -FFR 2635, Stream Ölçek at Ölçek, Kura drainage, 41.1340N, 42.8560E.

Distribution in the area. Kura River drainage.

\section{Remarks}

Among the species listed above, 26 are native and two of them (Oxynoemacheilus cyri and Leucalburnus satunini) are also endemic to the upper Kura River. L. satunini was 


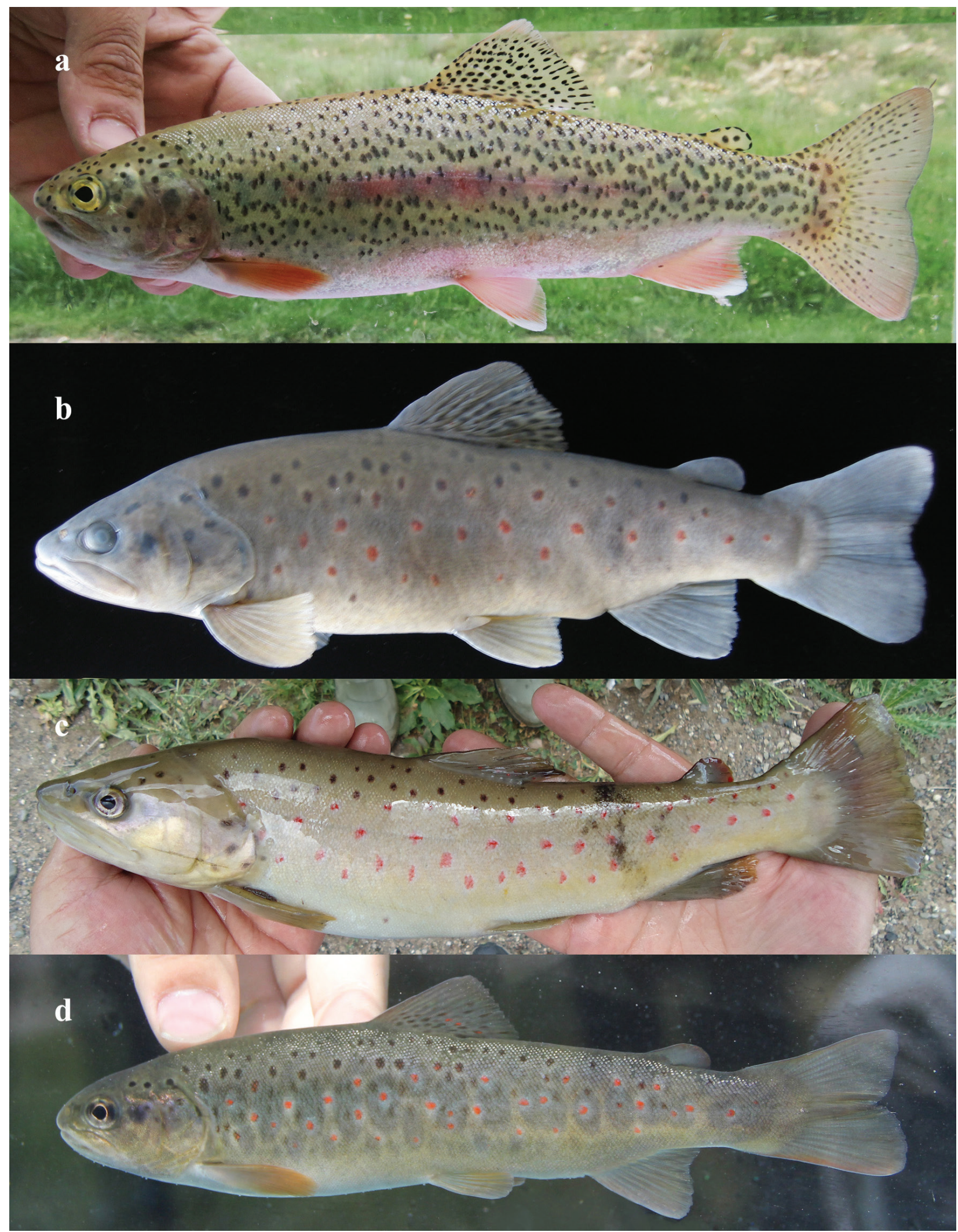

Figure 8. Salmonid species collected in the area, a, Oncorhynchus mykiss from Lake Çıldır, Aras; b, Salmo caspius from stream Çataldere, Kura; c, Salmo aff. caspius from stream İncilipınar, Aras; d, Salmo cf. ciscaucasicus from stream Keklik, Aras.

not included endemic fish species of Turkey by Çiçek et al. (2018). However, the species has never been reported from Armenia or adjacent countries. Even though these species are restricted to the Turkish part of Kura River, the population density detected was high. Probably, this was due to the limited human population in nearby rural 
areas, hence the negative effect of anthropogenic pollutants. In addition, hydro power plants could not be installed in the area since the geographical structure of the region is a flat plateau. Both species are already assessed as "Least concern" by IUCN.

Carassius gibelio, Cyprinus carpio, Pseudorasbora parva, Gobio artvinicus and Oncorhynchus mykiss are exotic species of upper Kura and Aras drainages. Even though P. parva and C. gibelio are not very widespread throughout the area, they have high invasiveness potential. Therefore, caution is necessary to prevent the spread of these species.

\section{Discussion}

Fricke et al. (2007) claimed that Caspiomyzon wagneri (Kessler, 1870), Acipenser persicus Borodin, 1897, Alosa braschnikovi (Borodin, 1904), Alosa caspia (Eichwald, 1838), Rutilus kutum (Kamensky, 1901), Stenodus leucichthys (Güldenstädt, 1772), Neogobius melanostomus (Pallas, 1814), Neogobius ratan (Pallas, 1814), Neogobius syrman (Pallas, 1814) and Proterorhinus marmoratus (Pallas, 1814) are extinct in the Caspian Sea watersheds of Turkey. However, these species had never been documented by field observations and collected specimens in Turkish Kura and Aras river drainages (See Table 2 for details). Furthermore, several incorrect records and misidentifications were identified (Table 2).

Alburnus hohenackeri, Blicca bjoerkna, Gobio artvinicus, Neogobius fluviatilis and Rhodeus amarus were recorded for the first time in the upper reaches of Aras River in Turkey by the observed samples.

Turan et al. (2012, 2014a, 2014b, 2017, 2020) showed that there is a high diversity within Salmonids in Anatolia. The presence of five trout species in Turkish Mediterranean tributaries and four species in Euphrates River drainages encouraged us to compare the trout population of Kura-Aras River systems in detail. Also based on a limited number of specimens, our study evidenced that Kura populations belong to Salmo caspius, but populations from Aras drainage need further study. We are considering the occurrence of $S$. ciscancasicus and an unnamed trout species in upper Aras drainages. Therefore, we encourage a detailed study on trout taxonomy in the upper Aras drainages.

Introduced salmonid, Coregenus albula, was recorded in Lake Aktaş, which is a transboundary lake shared between Turkey and Georgia (Yerli 2019). During our single survey in July 2017 in the Lake Aktaş, we were not able to find this species. Perhaps this species was introduced to the lake after the present survey.

There are two species categorized under the red list of IUCN; both were assessed as Vulnerable. The first is native populations of Cyprinus carpio, which were observed only in Lake Çıldır in the area. The population density of the species is declining due to overfishing and destruction of breeding and feeding areas (Zengin et al.
2012). Besides, invasive Pseudorasbora parva and Carassius gibelio, and introduced Cyprinus carpio inhabit Lake Çıldır and compete with the native $C$. carpio populations for food and habitat. The second species is Luciobarbus capito, which was found only in stream Gaziler in the present study. However, Çiçek and Sungur Birecikligil (2016) recorded the species in five sampling sites. We observed only 4 samples in stream Gaziler despite our intense efforts. This suggests that $L$. capito population is drastically declining due to damming in the 1950's and 1960 's in the Caspian Sea. L. capito decline is continuing, especially for mature individuals (Freyhof and Kottelat 2008). Because of its big size, overfishing is also a major threat for L. capito.

There are nine species not evaluated against IUCN criteria. Among these: Capoeta kaput, C. saniae and Oxynoemacheilus veyselorum, were described after 2017; therefore they have not yet been assessed by IUCN. $C$. kaput was found only from B-20 canal in this study, and from two localities by (Levin et al. 2019). C. saniae was described from two localities by Eagderi et al. (2017), which were covered by the present study and resulted in the capture of only a few specimens. $O$. veyselorum was described from a single locality by Çiçek (2018), however, in this study, it was recorded from eight additional sampling sites, with multiple individuals. The situation with respect to C. kaput and C. saniae, in particular, would appear to be critical. Therefore, we encourage researchers to study the conservation status of these species.

\section{Acknowledgements}

We would like to thank Mehmet Kuyumcu (Rize) and Şeyda Alınca (Iğdır) for their help during the fieldwork. Many thanks to Jörg Freyhof (Berlin) and Baran Yoğurtçuoğlu (Ankara) for their remarkable comments on the earlier version of this manuscript, and Lucas Nolan (Dublin) for improving its language.

Fish collections were approved and granted by the Ministry of Food, Agriculture and Livestock, General Directorate of Fisheries and Aquaculture (codes for the protocols: 67852565-140.03.03-E.4052273 and 76000869804.01-00000919222). All applicable international, national or institutional guidelines for the care and use of animals were followed.

\section{References}

Abbasi K, Valipour A, Talebi Haghighi D, Sarpanah A, Nezami Sh (1999) Atlas of Iranian Fishes. Gilan Inland Waters. Gilan Fisheries Research Centre, Rasht, 113 pp. [In Farsi]

Abdoli A (2000) The Inland Water Fishes of Iran. Iranian Museum of Nature and Wildlife, Tehran, 378 pp. [In Farsi]

Afraei Bandpei MA, El-Sayed MAF, Pourgholam R, Nasrolahzadeh H, Valinassab T (2012) Food and feeding habits of the Caspian marine shad, Alosa braschnikowi (Clupeidae) in the southern Caspian 
Sea. CYBIUM: International Journal of Ichthyology 36 (3): 411416. http://sfi-cybium.fr/en/food-and-feeding-habits-caspian-marine-shad-alosa-braschnikowi-clupeidae-southern-caspian-sea

Bayçelebi E (2019) Taxonomic revision of genus Squalius distributing in Turkey. PhD Thesis. Recep Tayyip Erdogan University, Institute of Science and Technology, Rize, Turkey, 135 pp.

Berg LS (1949) Freshwater Fishes of the U.S.S.R. and Adjacent Countries: Academy of Sciences of the U.S.S.R. Zoological Institute, I-IIIII: $341 \mathrm{pp}$.

Bogutskaya NG, Iliadou K (2006) Rutilus panosi, a new loach from western Greece (Teleostei: Cyprinidae). Zoosystematica Rossica 14(2): 293-298.

Bogutskaya NG, Zupančič P, Jelić D, Diripasko OA, Naseka AM (2017) Description of a new species of Alburnus Rafinesque, 1820 (Actinopterygii, Cyprinidae, Leuciscinae) from the Kolpa River in the Sava River system (upper Danube drainage), with remarks on the geographical distribution of shemayas in the Danube. ZooKeys 688: 81-110. https://doi.org/10.3897/zookeys.688.11261

Coad BW (2018) Review of the bitterlings of Iran (Family Acheilognathidae). Iranian Journal of Ichthyology 5(4): 257-267.

Coad BW (2020) Freshwater fishes of Iran. Retrieved from from: http:// www.briancoad.com [14 May 2020]

Çiçek E, Sungur Birecikligil S, Fricke R (2015) Freshwater fishes of Turkey: A revised and updated annotated checklist. Biharean Biologist 9(2): 141-157. http://biozoojournals.ro/bihbiol/cont/v9n2/ bb_151306_Cicek.pdf

Çiçek E, Sungur Birekcikligil S (2016) Ichthyofauna of the Turkish parts of Kura-Aras River Basin. Fishtaxa 1: 14-26. https://www. biotaxa.org/ft/article/view/21420/20581

Çiçek E (2018) Oxynoemacheilus veyseli, a new nemacheilid species from the upper Aras River drainage of Turkey (Teleostei: Nemacheilidae). Iranian Journal of Ichthyology 5(3): 232-242.

Derzhavin AN (1934) Presnovodnye ryby yuzhnogo poberezh'ya Kaspiya. Vstuplenie [Freshwater fishes of the southern shore of the Caspian Sea. Introduction]. Trudy Azerbaidzhanskogo Otdeleniya Zakavkazskogo Filiala Akademii Nauk SSSR, Sektor Zoologii, Baku, 7: 91-126.

Dorofeyeva EA (1967) Comparative morphological principles of the systematics of the east European salmon. Voprosy Ikhtiologii 7: 3-17. [In Russian]

Eagderi S, Jouladeh-Roudbar A, Jalili P, Sayyadzadeh G, Esmaeili HR (2017) Taxonomic status of the genus Cobitis Linnaeus, 1758 (Teleostei: Cobitidae) in the southern Caspian Sea basin, Iran with description of a new species. FishTaxa 2(1): 48-61.

Freyhof J, Kottelat M (2008) Luciobarbus capito. The IUCN Red List of Threatened Species 2008: e.T135687A4181037. https://doi. org/10.2305/IUCN.UK.2008.RLTS.T135687A4181037.en [Downloaded on 13 May 2020]

Freyhof J, Bayçelebi E, Geiger M (2018) Review of the genus Cobitis in the Middle East, with the description of eight new species (Teleostei: Cobitidae). Zootaxa 4535(1): 1-75. https://doi.org/10.11646/ zootaxa.4535.1.1

Fricke R, Bilecenoglu M, Sarı HM (2007) Annotated checklist of fish and lamprey species (Gnathostomata and Petromyzontomorphi) of Turkey, including a Red List of threatened and declining species. Stuttgarter Beiträge zur Naturkunde Seria A 706: 1-172.

Froese R, Pauly D (2020) FishBase. World Wide Web electronic publication. www.fishbase.org [version (02/2020)]
Geldiay R, Balık S (2007) Türkiye Tatlı Su Balıkları. Ege Üniversitesi Su Ürünleri Fakültesi yayınları, 166(6). [In Turkish]

Ghasemi H, Jouladeh Roudbar A, Eagderi S, Abbasi K, Vatandoust S, Esmaeili HR (2015) Ichthyofauna of Urmia basin: Taxonomic diversity, distribution and conservation. Iranian Journal of Ichthyology 2(3): 177-193. http://ijichthyol.org/index.php/iji/article/view/77/69

Holčík J, Oláh J (1992) Fish, fisheries and water quality in Anzali Lagoon and its watershed. Report prepared for the project Anzali Lagoon productivity and fish stock investigations. Food and Agriculture Organization, Rome, FI:UNDP/IRA/88/001 Field Document 2, 109 pp. http://www.fao.org/3/AD192E/AD192E00.htm

ICZN [International Code of Zoological Nomenclature] (1999) International Code of Zoological Nomenclature. $4^{\text {th }}$ Edition. International Trust for Zoological Nomeclature, London, $306 \mathrm{pp}$.

IUCN [International Union for the Conservation of Nature] (2020) IUCN Red List of threatened species. Version 2014.3. http://www. iucnredlist.org [20 January 2020]

Kaya C (2019) Taxonomic revision of the species belong to genus $\mathrm{Ca}$ poeta distributed in Turkey. PhD Thesis. Recep Tayyip Erdogan University, Institute of Science and Technology, Rize, Turkey, 126 pp.

Kessler KF (1877) The Aralo-Caspian Expedition. IV. Fishes of the Aralo-Caspio-Pontine ichthyological region. St. Petersburg. i-xxviii +1-360. [Pls. 1-8] [Supplement to: Trudy St. Petersburg. Obsh. Estestv.] https://doi.org/10.5962/bhl.title. 159366

Kiabi BH, Abdoli A, Naderi M (1999) Status of the fish fauna in the South Caspian Basin of Iran. Zoology in the Middle East 18: 57-65. https://doi.org/10.1080/09397140.1999.10637782

Kottelat M, Freyhof J (2007) Handbook of European freshwater fishes. Kottelat, Cornol \& Freyhof, Berlin, 646 pp.

Kuljanishvili T, Epitashvili G, Freyhof J, Japoshvili B, Kalous L, Levin B, Mustafayev N, Ibrahimov S, Pipoyan S, Mumladze L (2020) Checklist of the freshwater fishes of Armenia, Azerbaijan and Georgia, Journal of Applied Ichthyology 00: 1-14. https:/doi. org/10.1111/jai.14038

Kuru M (1975) Dicle-Fırat, Kura-Aras, Van Gölü Karadeniz Havzası Tatlısularında Yaşayan Balıkların (Pisces) Sistematik ve Zoocoğrafik Yönden İncelenmesi. Doçentlik Tezi. Atatürk Üniversitesi, Fen Fakültesi, Erzurum, 180 pp. [in Turkish]

Kuru M (2004) Türkiye İçsu Balıklarının Son Sistematik Durumu. Gazi Üniversitesi, Gazi Eğitim Fakültesi Dergisi 24(3): 1-21. [in Turkish] http://www.gefad.gazi.edu.tr/tr/download/article-file/77288

Küçük F, Bektaş Y, Güçlü SS, Kaya C (2014) The systematic position of Acanthalburnus microlepis (De Filippi, 1863) and contributions to the genus Acanthobrama (Cyprinidae: Leuciscinae) in Turkey. Iranian Journal of Ichthyology 2: 96-105. http://www.ijichthyol.org/ index.php/iji/article/view/44/31

Levin BA, Prokofievc AM, Roubenyan HR (2019) A new species of algae eaters Capoeta kaput sp. nov. (Teleostei, Cyprinidae) from Transcaucasia. Inland Water Biology 12: 32-41. https://doi. org/10.1134/S1995082919010139

Perea S, Böhme M, Zupančič P, Freyhof J, Šanda R, Özuluğ M, Abdoli A, Doadrio I (2010) Phylogenetic relationships and biogeographical patterns in Circum-Mediterranean subfamily Leuciscinae (Teleostei, Cyprinidae) inferred from both miotochondrial and nuclear data. BMC Evolutionary Biology 10: 265. https://doi.org/10.1186/14712148-10-265

Pinchuk VI, Vasil'eva ED, Vasil'ev VP, Miller P (2003) (Neogobius fluviatilis (Kessler, 1857)). In: The Freshwater Fishes of Europe. 
Mugilidae, Atherinidae, Atherionopsidae, Blennidae, Odontobutidae, Gobiidae 1, 8 (I): [ed. by Miller P]. Wiesbaden, AULA-Verlag. 223-264.

Pipoyan SK (1996) Bitterling Rhodeus (sic) sericeus amarus, a new species in the fauna of Armenia. Journal of Ichthyology 36(8): 676-678.

Poursaeid S, Falahatkar B (2012) Threatened fishes of the world: Stenodus leucichthys leucichthys Güldenstädt, 1772 (Salmonidae). Aqua International Journal of Ichthyology 18: 1-15.

Sayyadzadeh G, Abbasi K, Esmaeili HR (2018) Review and re-description of Sabanejewia species in Iran (Teleostei: Cobitidae). Iranian Journal of Ichthyology 5(4): 267-292.

Turan D (2003) Rize ve Artvin Yöresindeki Tatlısu Balıklarının Sistematik ve Ekolojik Yönden İncelenmesi. Phd thesis. İzmir: Ege Üniversitesi Fen Bilimleri Enstitüsü, 179 pp. [in Turkish]

Turan D, Kottelat M, Engin S (2012) The trouts of the Mediterranean drainages of southern Anatolia, Turkey, with description of three new species (Teleostei: Salmonidae). Ichthyological Exploration of Freshwaters 23(3): 219-236. https://doi.org/10.11646/zootaxa.2993.1.2

Turan D, Kottelat M, Engin S (2014a) Two new species of trouts from the Euphrates drainage, Turkey (Teleostei: Salmonidae). Ichthyological Exploration of Freshwaters 24: 275-287. https:/www. pfeil-verlag.de/wp-content/uploads/2017/04/ief24_3_08.pdf
Turan D, Doğan E, Kaya C, Kanyılmaz M (2014b) Salmo kottelati, a new species of trout from Alakır Stream, draining to the Mediterranean in southern Anatolia, Turkey (Teleostei, Salmonidae). Zookeys 462: 135-151. https://doi.org/10.3897/zookeys.462.8177

Turan D, Kottelat M, Kaya C (2017) Salmo munzuricus, a new species of trout from the Euphrates River drainage, Turkey (Teleostei: Salmonidae), Ichthyological Exploration of Freshwaters 28(1): 55-63. https://pfeil-verlag.de/wp-content/uploads/2017/07/ ief28_1_04.pdf

Turan D, Kalayci G, Bektaş Y, Kaya C, Bayçelebi E (2020) A new species of trout from the northern drainages of Euphrates River, Turkey (Salmoniformes: Salmonidae). Journal of Fish Biology 1-9. https:// doi.org/10.1111/jfb.14321

Van Der Laan R, Eschmeyer WN, Fricke R (2014) Family-group names of Recent fishes. Zootaxa 3882(1): 230. https://doi.org/10.11646/ zootaxa.3882.1.1

Yerli SV (2019) First record of a coregonid fish species, Coregenus albula (Linnaeus, 1758) (Salmoniformes: Salmonidae) in Aktaş Lake shared between Turkey and Georgia. Journal of the Black Sea / Mediterranean Environment 25(3): 325-332.

Zengin M, Yerli SV, Dağtekin M, Akpınar İÖ (2012) Çıldır Gölü balıkçılığında son yirmi yılda meydana gelen değişimler. SDÜ Eğridir Su Ürünleri Fakültesi Dergisi 8(2): 10-24. https://dergipark. org.tr/tr/pub/egirdir/issue/23055/246414 